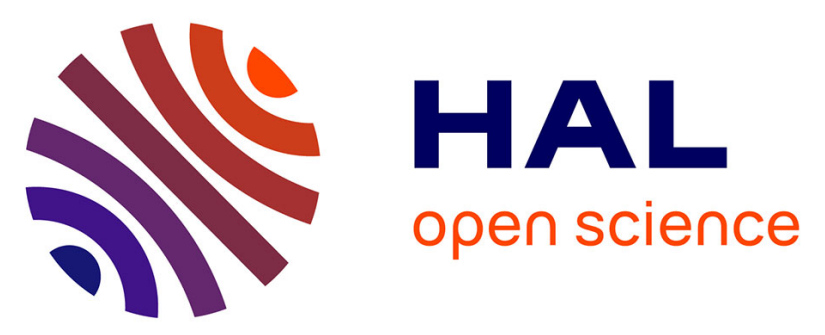

\title{
Seismicity Distribution Near a Subducting Seamount in the Central Ecuadorian Subduction Zone, Space-Time Relation to a Slow-Slip Event
}

Mónica Segovia, Yvonne Font, Marc Regnier, Philippe Charvis, Audrey Galvé, Jean-Mathieu Nocquet, Paul Jarrin, Yann Hello, Mario Ruiz, Andres Pazmiño

\section{To cite this version:}

Mónica Segovia, Yvonne Font, Marc Regnier, Philippe Charvis, Audrey Galvé, et al.. Seismicity Distribution Near a Subducting Seamount in the Central Ecuadorian Subduction Zone, Space-Time Relation to a Slow-Slip Event. Tectonics, 2018, 37 (7), pp.2106-2123. 10.1029/2017TC004771 . hal02196121

\section{HAL Id: hal-02196121 \\ https://hal.science/hal-02196121}

Submitted on 16 Sep 2021

HAL is a multi-disciplinary open access archive for the deposit and dissemination of scientific research documents, whether they are published or not. The documents may come from teaching and research institutions in France or abroad, or from public or private research centers.
L'archive ouverte pluridisciplinaire HAL, est destinée au dépôt et à la diffusion de documents scientifiques de niveau recherche, publiés ou non, émanant des établissements d'enseignement et de recherche français ou étrangers, des laboratoires publics ou privés. 


\section{Tectonics}

\section{RESEARCH ARTICLE}

10.1029/2017TC004771

Key Points:

- The microseismicity is well imaged with a temporary and dense onshore-offshore seismic network in central Ecuador

- Deep onshore seismicity seems to be controlled by the interface coupling and the rheology of the upper crust

- An offshore seismic swarm in secondary faults in the oceanic crust accompanies a slow slip

Supporting Information:

- Supporting Information S1

- Figure S1

- Figure S2

- Table S1

- Table S2

Correspondence to:

M. Segovia,

msegovia@igepn.edu.ec

Citation

Segovia, M., Font, Y., Régnier, M., Charvis, P., Galve, A., Nocquet, J.-M., et al. (2018). Seismicity distribution near a subducting seamount in the Central Ecuadorian subduction zone, space-time relation to a slow-slip event. Tectonics, 37, 2106-2123. https://doi. org/10.1029/2017TC004771

Received 16 AUG 2017 Accepted 18 JUN 2018 Accepted article online 26 JUN 2018 Published online 20 JUL 2018

\section{Seismicity Distribution Near a Subducting Seamount in the Central Ecuadorian Subduction Zone, Space-Time Relation to a Slow-Slip Event}

\author{
Mónica Segovia ${ }^{1,2} \mathbb{D}$, Yvonne Font ${ }^{2}$, Marc Régnier ${ }^{2}$, Philippe Charvis ${ }^{2}$ iD, Audrey Galve ${ }^{2}$ iD, \\ Jean-Mathieu Nocquet ${ }^{2}$ (D), Paul Jarrín ${ }^{1}$, Yann Hello ${ }^{2}$, Mario Ruiz ${ }^{1}$ (D) and Andres Pazmiño ${ }^{3}$ \\ ${ }^{1}$ Instituto Geofísico, Escuela Politécnica Nacional, Quito, Ecuador, ${ }^{2}$ Géoazur, IRD, CNRS, Observatoire de la Côte d'Azur, \\ Université Côte d'Azur, Valbonne, France, ${ }^{3}$ Instituto Oceanográfico de la Armada, Guayaquil, Ecuador
}

Abstract A temporary onshore-offshore seismic network deployed during the 2-year period of the Observación SISmológica en ECuador project provides a detailed and well-focused image of the seismicity for magnitudes as low as 2.1 at the Central Ecuadorian subduction zone. During this 2-year experiment, the shallow and locked subduction patch shows little evidence of background seismicity that instead occurred downdip of the coupled patch at $\sim 20-\mathrm{km}$ depth. In this region, seismicity is possibly controlled by the crustal faults bounding the sedimentary basin of Manabí and the rheology of the upper plate. The dip angle of the interplate contact zone, defined by a smooth interpolation through the hypocenters of thrust events, is consistent with a progressive increase from $6^{\circ}$ to $25^{\circ}$ from the trench to 20-km depth. Offshore, a seismic swarm, concomitant with a slow-slip event rupturing the highly coupled subduction megathrust, highlights the reactivation of secondary active faults within the thickened crust of the subducting Carnegie Ridge at the leading edge of a large oceanic seamount.

\section{Introduction}

The degree of interseismic coupling (ISC), derived from the inversion of interseismic geodetic data, highlights the moment deficit accumulation and the potential to generate large earthquakes. Locking along a subduction megathrust is heterogeneous in space and time with a juxtaposition of areas of stable sliding, transient slow slip, and stick slip. Microseismic activity is often concentrated the transitions between locked and creeping areas (e.g., Chlieh et al., 2004, 2014; Métois et al., 2012; Nocquet et al., 2014; Schwartz \& DeShon, 2007; Schwartz \& Rokosky, 2007). Earthquake swarms along subduction megathrusts are common, and they are often associated with reduced interplate coupling and coincide with areas acting as barriers to large earthquake rupture propagation (Holtkamp \& Brudzinski, 2014). These authors suggest that they are possibly related to stress heterogeneity. Along the South American subduction megathrust most earthquake swarms are located where major volcanic ridges are currently subducting beneath South America (Holtkamp et al., 2011).

In Ecuador, the subduction of the Nazca Plate, which carries the large Carnegie Ridge, is characterized by the transition between a highly locked subduction interface, north of latitude $0.5^{\circ} \mathrm{S}$, and an almost unlocked portion to the south (Chlieh et al., 2014; Nocquet et al., 2014). In Central Ecuador, within the unlocked area, a shallow and discrete highly coupled patch extends beneath La Plata Island ( $/$ in Figure 1; Chlieh et al., 2014; Nocquet et al., 2014). No large historical earthquakes are known in this area (Chlieh et al., 2014), but it has instead undergone numerous seismic swarms (Font et al., 2013; Holtkamp et al., 2011; Holtkamp \& Brudzinski, 2011; Segovia, 2001, 2009; Vaca et al., 2009) and several slow-slip events (SSEs; Segovia et al., 2015; Vallée et al., 2013). Two of those swarms have been detected using the Preliminary Determination of Epicenters catalog, in 1977 and in 2005, at the intersection of the Carnegie Ridge and the subduction zone (Holtkamp et al., 2011). Thus far, the seismic swarms and the background seismicity in this area have remained poorly resolved by the national seismic network RENSIG (Red Nacional de Sismógrafos del Instituto Geofísico de la Escuela Politécnica Nacional). In this study, we present results using a temporary, dense, onshore-offshore seismic network during the OSISEC experiment (Observación SISmológica en ECuador) from June 2011 to October 2013. The dense network allowed us to better detect and locate earthquakes providing a precise determination of the geometry of the plate interface and secondary faults. Here 


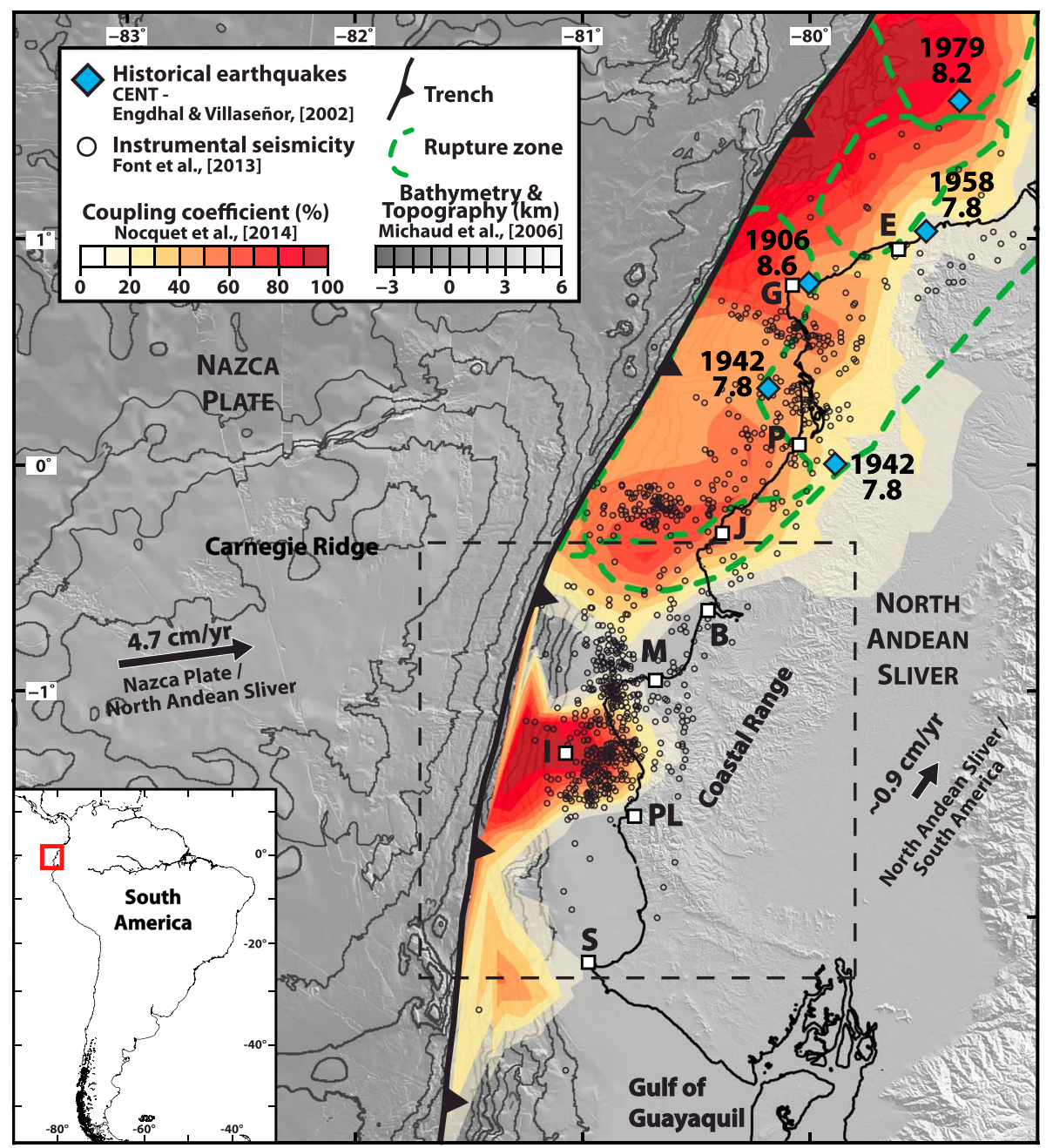

Figure 1. Bathymetric and topographic map of Ecuador (after Michaud et al., 2006) showing the geodynamic context of the Ecuadorian subduction zone (bathymetric contour line every $500 \mathrm{~m}$ ). The distribution of the interseismic coupling along the Ecuadorian subduction zone derived from the inversion of the interseismic GPS velocities is from Nocquet et al. (2014). The relative convergence rates are from Nocquet et al. (2014). Green dashed lines show rupture areas of historical earthquakes in 1942, 1958, 1979, and 1906 (modified from Collot et al., 2004; Kelleher, 1972; Mendoza \& Dewey, 1984). Epicenters of historical earthquakes (blue diamonds) are from Engdahl and Villaseñor (2002) and Mendoza and Dewey (1984). Black circles: Instrumental seismicity between 1994 and 2007 (Font et al., 2013). Toponymy: E = Esmeraldas, $\mathrm{G}=$ Punta Galera, P = Pedernales, J = Jama, B = Bahía, M = Manta, I = La Plata Island, PL = Puerto López, and S = Salinas. Dashed black frame: Observación SISmológica en ECuador study area. The thick line with triangles indicates the trench position.

we discuss the correlation between seismicity and the interseismic locking determined from GPS data, the microseismicity concomitant with a SSE that occurred during the time of our experiment, and the factors controlling the location of microseismicity.

\section{Geodynamical Setting}

Along the northwestern coast of South America, the Nazca Plate (NAZ) subducts beneath the North Andean Sliver (NAS, also named the North Andean Block) at a rate of $4.7 \mathrm{~cm} /$ year in a $\mathrm{N} 81^{\circ} \mathrm{E}$ direction (Nocquet et al., 2014; Figure 1). In front of Central Ecuador, the crust of the Nazca Plate is thickened by up to 14-19 km beneath the Carnegie Ridge. It is a major volcanic feature related to the activity of the Galápagos hot spot $\sim 25 \mathrm{Myr}$ ago, which stands approximately 2,000 $\mathrm{m}$ above the seafloor (Sallarès \& Charvis, 2003; Sallarès et al., 2005). The geometry and depth of the Moho of the subducting Nazca Plate were previously defined by a 
wide-angle seismic profile (Collot et al., 2017; Gailler et al., 2007; Graindorge et al., 2004). The E-W profile viewed at $1.4^{\circ} \mathrm{S}$ shows the subduction interface from the trench to $\sim 60 \mathrm{~km}$ eastward where it lies at 10-km depth with a dip angle of $\sim 10^{\circ}$.

At these latitudes, the forearc region consists of a rigid block, the NAS, moving at a rate of $\sim 0.9 \mathrm{~cm} / y e a r$ in a $\mathrm{N} 35^{\circ} \mathrm{E}$ direction with respect to the stable South American Plate (Nocquet et al., 2014). The NE motion of the NAS and the opening of the Gulf of Guayaquil are likely related to the obliquity of the relative convergence north of Ecuador (Nocquet et al., 2014; Witt et al., 2006). The basement of the NAS consists of oceanic terranes accreted to the South American paleomargin between the Cretaceous and Late Eocene times. The forearc basins that overlay this basement contain volcanosedimentary deposits of Late Cretaceous to Paleocene ages and marine sediments with Neogene to Quaternary ages (Jaillard et al., 1997, 2009; Luzieux et al., 2006; Reyes, 2013). In the forearc, the Coastal Range, a major feature of approximately $400 \mathrm{~km}$ long and up to $800 \mathrm{~m}$ high, is parallel to the shoreline. Coastal terraces in the Manta Peninsula and the Isla de la Plata have been rising for at least $300 \mathrm{kyr}$ in front of the Carnegie Ridge (Pedoja et al., 2006).

The Ecuadorian subduction zone can be divided into two main segments with distinct interseismic locking levels highlighted by GPS results. North of the central axis of the Carnegie Ridge (i.e., from the latitude of Bahía de Caráquez, B in Figure 1), the subduction megathrust is highly locked (Chlieh et al., 2014; Nocquet et al., 2014). Along this segment, four historical large subduction earthquakes, with magnitudes ranging between 7.8 and 8.8, occurred in 1906, 1942, 1958, and 1979 (Beck \& Ruff, 1984; Kanamori \& McNally, 1982; Kelleher, 1972; Mendoza \& Dewey, 1984), and more recently on 16 April 2016 (Mw = 7.8, near Pedernales, $P$ in Figure 1; Nocquet et al., 2016). South of $0.5^{\circ} \mathrm{S}$, low to null ISC is observed, which is consistent with the lack of great subduction earthquakes (Chlieh et al., 2014; Dorbath et al., 1990; Nocquet et al., 2014). This uncoupled segment extends down to Northern Peru (Nocquet et al., 2014; Villegas-Lanza et al., 2016).

The study area is located at the northern end of the uncoupled southern segment. There, a $\sim 40 \times 40-\mathrm{km}^{2}$ highly coupled patch (i.e., up to 90\%; Chlieh et al., 2014; Collot et al., 2017; Nocquet et al., 2014) is embedded within the uncoupled segment (Figure 1). This highly coupled patch has been interpreted as a discrete seismic asperity (Chlieh et al., 2014) despite the lack of significant historical subduction earthquakes. Constrained by a continuous GPS station located on La Plata Island (located $\sim 35 \mathrm{~km}$ east of the trench), the locked patch extends about $40 \mathrm{~km}$ along dip, from the trench to 20-25-km depth (Collot et al., 2017; Figure 1). This shallow locked patch spatially correlates with the subduction of an oceanic seamount that is part of the Carnegie Ridge (Collot et al., 2017). Moderate seismic activity has been recorded in this location since 1977 with the occurrence of intense and repetitive seismic swarms detected in 1977, 1993, 1996, 1998, 2002, 2005, 2010, and 2013, lasting from weeks to months (Font et al., 2013; Holtkamp et al., 2011; Segovia, 2001, 2009; Vaca et al., 2009; Vallée et al., 2013) with individual seismic events as large as Mw =6. Coincident with the 2010 swarm, a 5-day long SSE with an equivalent magnitude of 6.0-6.3 was detected beneath La Plata Island (Vallée et al., 2013). More recently, in January 2013, during the OSISEC experiment, we recorded a weeklong swarm of earthquakes that accompanied a new SSE (Segovia et al., 2015).

\section{Seismic Data Acquisition and Processing}

\subsection{Network}

The OSISEC network was progressively installed between June and October 2011 and recorded continuously until October 2013. It included 5 Ocean Bottom Seismometers (OBS, Guralp CMG-40T sensor 30 s period and HighTech Inc., wide-band hydrophones; Hello et al., 2006) and 11 broadband land stations among which 6 are temporary (Nanometrics Trillium Compact sensors, $120 \mathrm{~s}$ ) and 5 are part of the permanent network RENSIG installed mainly during the French-Ecuadorian Andes du Nord project (Guralp CMG-3ESPC sensors, 60 s). OBSs from Géoazur laboratory were deployed on the continental slope, at about 1,000-m depth, in an area free from bottom trawling. The OBS were evenly spaced at 10-km intervals, whereas land stations were spaced at $\sim 15-\mathrm{km}$ intervals (Figure 2 ). Both types of temporary stations were operated in continuous recording mode with a sampling rate of $100 \mathrm{~Hz}$, while the permanent RENSIG stations have a sampling rate of $125 \mathrm{~Hz}$. For the OBSs, sea-bottom instability and/or marine currents resulted in incomplete recordings of the velocimeter components, and therefore, the arrival times were mainly measured on the hydrophone components. Consequently, no $S$ waves have been picked on marine stations. 

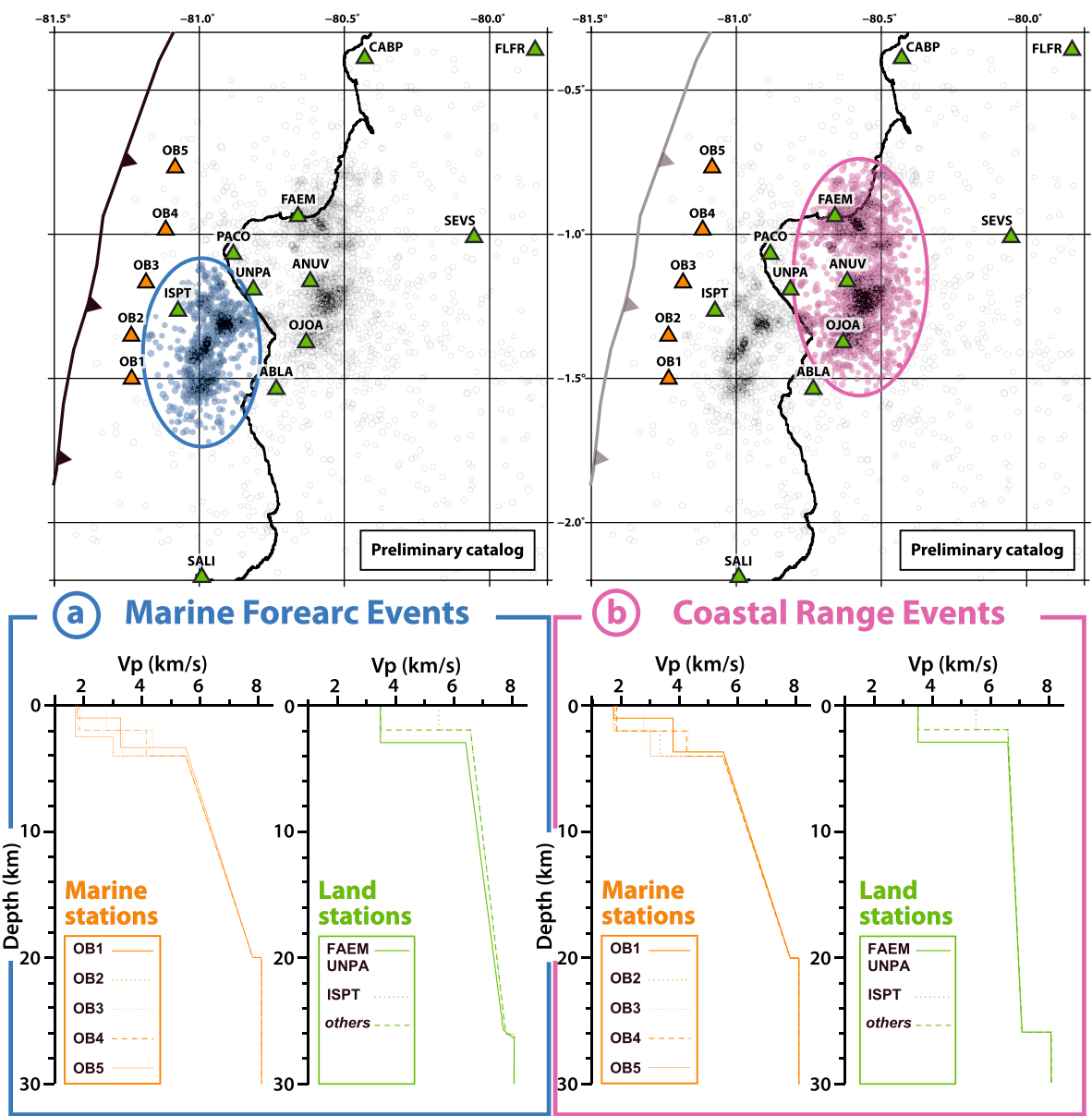

Figure 2. Map distribution of offshore (top left) and onshore seismicity (top right) used to obtain the corresponding ensembles of best 1-D velocity models for the (a) marine forearc and (b) Coastal Range events. Ocean Bottom Seismometers (orange triangles) and land station locations (green triangles) are indicated.

\subsection{Data Processing}

The seismic events were detected using an STA/LTA algorithm (the traces were band-pass filtered between 5 and $10 \mathrm{~Hz}$ ) and confirmed with a coincidence of triggers at a minimum of three stations. Part of the continuous traces were also inspected visually to ascertain that the STA/LTA filter was sensible enough to detect most of the seismic events. All phase arrivals, polarities, and maximum amplitude were picked manually.

We located 3,900 events (between June 2011 and January 2013) recorded by an average of six ( \pm 2.6 ) stations ( 21,485 and 9,494 $P$ and $S$ arrivals, respectively). We used software developed by one of us (MR) for manual picking and to compute hypocenter locations. The latter method uses a nonlinear grid search algorithm to find the hypocenter and the origin time of the earthquakes (Vaca et al., 2018). This program also allows the use of several velocity models, either with constant velocity or gradient velocity layers.

Preliminary locations (shown in Figure 2) used a single 1-D model with constant velocity layers derived from the velocity model of Graindorge et al. (2004). This model has a 2-km-thick sedimentary layer with $V p=2.5 \mathrm{~km} / \mathrm{s}$, a 24-km-thick crustal layer with a $P$ velocity equal to $6.5 \mathrm{~km} / \mathrm{s}$ and a semispace mantle layer with $V p=8.1 \mathrm{~km} / \mathrm{s}$. The $V p / V s$ ratio was set to 1.73 . Preliminary locations exhibit two main regions of high seismic activity. The first region is located offshore, in the marine forearc (blue circles in Figure 2a), where the plate interface is probably shallower than $10 \mathrm{~km}$ (Gailler et al., 2007; Graindorge et al., 2004). The second active region is located onshore (purple circles on Figure $2 \mathrm{~b}$ ), beneath the Coastal Range (Figure 1).

To assess the inadequacies of the initial 1-D model with respect to the azimuthal distribution of earthquakes, we analyze the traveltime residues at each station while considering the arrivals coming from each main 
cluster separately (i.e., marine forearc and Coastal Range regions). First, we observed that the residual distribution at each land station shows different averages for earthquakes located offshore and those located onshore. Second, the residual distribution pattern is different for marine stations (OBSs), which present much larger standard deviations and no Gaussian distributions for the earthquakes located in both domains. This observation demonstrates that the velocity model beneath the OBS strongly differs from the one beneath the land stations. In previous studies, the residual pattern at the OBSs have been linked to the thickness of low-velocity sedimentary layers beneath each OBS (Castagna et al., 1985; Hirata et al., 1983; Pontoise \& Monfret, 2004; Ruiz et al., 2011). In order to account for these heterogeneities, we searched for optimum 1-D models for land and marine stations, analyzing the $P$ and $S$ arrivals from the offshore and onshore clusters separately (e.g., Husen et al., 2011, for similar type of analysis).

\subsection{Best 1-D Gradient Velocity Models}

The search for optimum velocity models is conducted from a selection of events well recorded at a minimum of six nearby stations and with an azimuthal gap smaller than $120^{\circ}$.

The starting model is composed of one or two sedimentary layers with constant velocity, a velocity gradient midcrustal layer, and a half-space representing the upper mantle ( $P$ wave velocity is set to 8.1 , after Graindorge et al., 2004). For land stations, the sedimentary layer thickness and $V p$ are set according to the on-land forearc sedimentary basins described by Reyes and Michaud (2012). OBSs sit on poorly compacted marine sediments, saturated with seawater, characterized by low $V p$ and high $V p / V s$, which are known to bias earthquake location (Castagna et al., 1985; Hirata et al., 1983; Pontoise \& Monfret, 2004; Ruiz et al., 2011). To account for those local effects, we introduce two low-velocity layers with constant velocity, on top of the midcrustal layer, whose characteristics are derived from the joint interpretation of available multichannel and refraction seismic lines (Gailler et al., 2007; Graindorge et al., 2004; Proust et al., 2016). At local scale, we expect Pn phase arrival times to be correctly modeled by a simple velocity contrast at the crust-mantle boundary.

The search for the best 1-D velocity model is based on a Monte Carlo approach. Four parameters result from the inversion of traveltimes defining the midcrustal layer by its top velocity, velocity gradient, Vp/Vs ratio, and thickness. Due to the small number of perturbed parameters, a systematic grid search was performed. The best crustal velocity model is the one that best minimizes the sum of root-mean-square (RMS) over the events selected. Additionally, the thicknesses of the sedimentary layer were adjusted in order to minimize traveltime residuals at seismic stations (individually or by group).

With this strategy, we computed two sets of optimum 1-D gradient velocity models: one using arrival times from the marine forearc events, the other one, using arrival times from Coastal Range events (Figures 2a and $2 \mathrm{~b}$, respectively). Each ensemble consists of several distinct 1-D best velocity models (five models for five OBS and three models for the land stations, Figure 2), which exhibit various low-velocity sedimentary layers accounting for local effects beneath each seismometer. On the contrary, seismic velocities in the midcrustal layer is very consistent beneath onshore and offshore stations. This approach enables us to build velocity models that are able to take into account on the one hand the traveltime delay related to the site effect beneath each station (the thickness of low-velocity sedimentary layers) and on another hand the traveltime in the igneous crust and upper mantle between the event and the seismometer.

\subsubsection{Velocity Models for Land Stations}

The resolved $P$ velocity $(6.6 \mathrm{~km} / \mathrm{s})$ at the top of the crustal layer is similar for offshore and onshore events. This velocity is slightly higher than the Vp given by Graindorge et al. (2004) or Gailler et al. (2007) based on wideangle seismic modeling of an E-W seismic profile located at $1.4^{\circ} \mathrm{S}$. Both authors attribute such high velocities to the Piñón Formation, Cretaceous basalts, and dolerites with oceanic plateau affinity (Mamberti et al., 2003), which compose the basement of the accreted oceanic terranes and outcrops onshore in the forearc domain and on La Plata Island (Jaillard et al., 1997, 2009; Luzieux et al., 2006; Reyes, 2013). The resolved Vp/Vs ratio range from 1.78 to 1.80 , respectively, for offshore and onshore events, which is likely within the determination error. The resolved velocity gradient is very small and differs slightly from $0.04 \mathrm{~km} / \mathrm{s} / \mathrm{km}$ for offshore events to $0.02 \mathrm{~km} / \mathrm{s} / \mathrm{km}$ for onshore events suggesting weak lateral velocity variations in the crust sampled by seismic rays.

\subsubsection{Velocity Models for Marine Stations}

The first sedimentary layer is 1 to $2.5 \mathrm{~km}$ thick (depending on the OBS) with a $V p$ as low as $1.7 \mathrm{~km} / \mathrm{s}$, which represents the marine sediment sequence. The second and deeper layer with a $V p$ from 2.5 to $4.4 \mathrm{~km} / \mathrm{s}$ 
Table 1

Threshold Values and Conditions Used to Categorize the 3,907 Earthquakes in $A, B, C, D$, and $E$ Class

\begin{tabular}{lcccccc}
\hline Class & ex $(\mathrm{km})$ & ey $(\mathrm{km})$ & ez $(\mathrm{km})$ & $\mathrm{Gap}\left({ }^{\circ}\right)$ & $D \min (\mathrm{km})$ & $\mathrm{RMS}(\mathrm{s})$ \\
\hline $\mathrm{A}$ & $<0.7$ & $<0.7$ & $<0.7$ & $<150$ & $<25$ & $<0.3$ \\
$\mathrm{~B}$ & $<1.5$ & $<1.5$ & $<1.5$ & $<210$ & $<45$ & $<0.35$ \\
$\mathrm{C}$ & $<2.5$ & $<2.5$ & $<2.5$ & $<270$ & $<65$ & $<0.42$ \\
$\mathrm{D}$ & $<3.0$ & $<3.0$ & $<3.0$ & $>270$ & $>65$ & $>0.42$ \\
$\mathrm{E}$ & $>3.0$ & $>3.0$ & $>3.0$ & - & - & - \\
\hline
\end{tabular}

Note. ex, ey, and ez: uncertainty in the $\mathrm{E}-\mathrm{W}, \mathrm{N}-\mathrm{S}$, and depth direction, respectively. Gap is azimuthal gap (in degrees). Dmin is the minimum station-to-earthquake distance $(\mathrm{km})$. RMS is the residual root-meansquare $(\mathrm{s})$ and a thickness ranging from 1.5 to $2.6 \mathrm{~km}$ possibly represents the volcanoclastic Cayo formation (Gailler et al., 2007). Since no $S$ waves were identified on OBS data, the $V p / V s$ ratio is meaningless in these first two layers. Beneath all of the OBSs, the crustal layer is $\sim 16 \mathrm{~km}$ thick, the velocity is $5.5 \mathrm{~km} / \mathrm{s}$ at the top with a $V p$ gradient of $0.13 \mathrm{~km} / \mathrm{s} / \mathrm{km}$ and a $V p / V s$ ratio of 1.78 (Table S1 in the supporting information and Figure 2).

The 1,087 and 2,821 hypocenters were determined respectively offshore and onshore using the corresponding ensemble of optimum velocity models. Resulting residual RMS significantly decrease from 0.25 to $0.13 \mathrm{~s}$ for the marine earthquakes and from 0.23 to $0.18 \mathrm{~s}$ for onland earthquakes.

\subsection{Hypocenter Location Uncertainties and Earthquake Selection}

Our location method does not provide formal errors in the hypocenter determination. Since those errors may be attributed to several sources from the velocity model to picking errors, we chose to evaluate at least the impact of arrival times on the solution.

To quantify the uncertainties due to errors on phase reading on the hypocenter determination, we use a bootstrap approach similar to the Monte Carlo analysis proposed by Billings et al. (1994). The strategy is based on the random perturbation of the phase readings and subsequent relocation. We perturb arrival times by adding a randomly generated value within $\pm 0.1 \mathrm{~s}$ for $P$ arrivals and $\pm 0.25 \mathrm{~s}$ for $S$ arrivals. For each earthquake, we generate 150 sets of perturbed arrival times providing 150 relocated hypocenter solutions. The hypocenter location uncertainty for each earthquake is then defined as one standard deviation over the mean of mislocations.

We sorted out the seismic events into five groups according to their quality defined by vertical and horizontal errors, the traveltime residual RMS, the distance to the closest station and the azimuthal gap. Earthquakes are classified in a category when all six required parameters fulfill the threshold conditions given in Table 1. The worst quality E class contains events with ex, ey, or ez (errors in kilometers along E-W, N-S, or depth directions, respectively) greater than $3 \mathrm{~km}$.

For this study, we discard all E-quality events ( $38 \%$ of the total). The final OSISEC catalog then includes 2,439 events of quality $A$ to $D$ (Figure 3 and Table 2), providing a catalog with location uncertainties lower than $3 \mathrm{~km}$. We note that the categorization of events is mainly controlled by the azimuthal gap rather than by the number of stations (Table 1). The limited number of high-quality locations ( $A$ and $B$ class represent $\sim 22 \%$ of the total number of earthquakes) is due to the small number of events with an azimuthal gap lower than $210^{\circ}$.

\subsection{Magnitude Determination}

Our determination of a local magnitude for the OSISEC catalog relies on the use of the local magnitude (MI) computed in the national RENSIG seismic catalog. To build a local magnitude relationship, we selected the 41 earthquakes that match both catalog. Their MI ranges between 2.5 and 5.0. Based on the known RENSIG magnitudes, we standardized a ML relation for each land station of the OSISEC network (equation (1)). The local magnitude $M_{\mathrm{ij}}$ for an event $j$ from equation (1) is based on the measure of the maximum amplitude of the seismogram recorded at a station $i$,

$$
M_{i j}=a_{i} \times \log A_{i j}+b_{i} \times \log \Delta_{i j}+c_{i}
$$

where $i$ : station; $j$ : seismic event; $a_{i}, b_{i}$ and $c_{i}$ : coefficients for station $i ; A_{i j}$ : maximum amplitude for the event $j$ at the station $i$ measured automatically on a seismic trace filtered between 1 and $10 \mathrm{~Hz} ; \Delta_{i j}$ : distance between the station $i$ and the seismic event $j$. The local magnitude (Ml) assigned to the earthquake is the mean of the magnitudes computed at the recording stations. On average, $4.2( \pm 1.5)$ amplitude measurements are used to determine the magnitudes of the 41 reference events and establish the $a, b$, and $c$ coefficients at each land station that will then serve to calculate the magnitude for the whole OSISEC catalog. For those events, the mean variation between the magnitudes is $-0.007( \pm 0.12)$. 


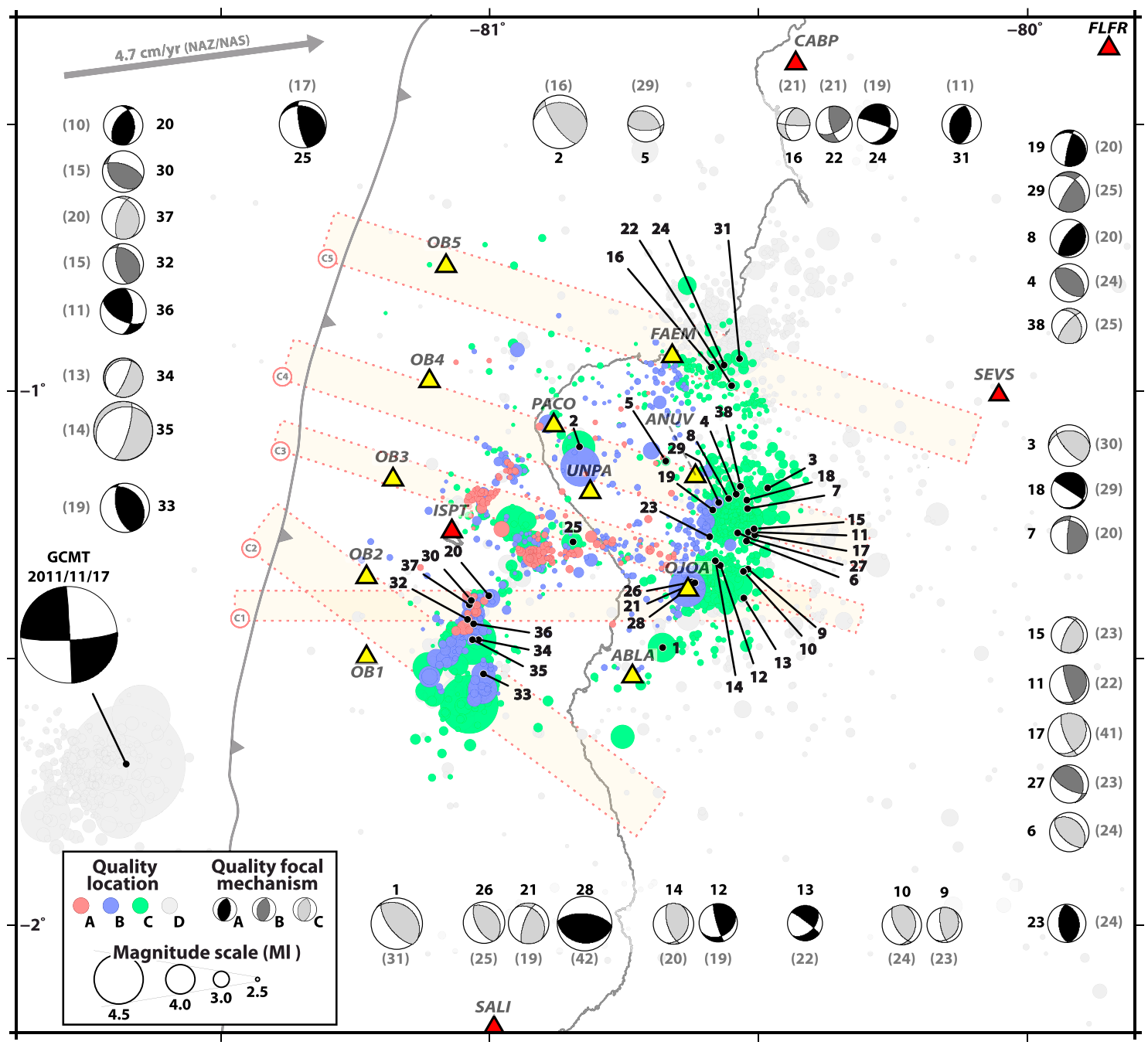

Figure 3. Map of seismicity from earthquake location within the best 1-D gradient velocity models ( 2,700 seismic events) and focal mechanisms (black and gray texts refer to the identification number and earthquake depth in Table S2). Focal mechanism from Global Centroid Moment Tensor of the 17 Nov 2011 , 6.0 Mw is also included (Dziewonski et al., 1981; Ekström et al., 2012). Yellow triangles: Observación SISmológica en ECuador stations. Red triangles: Red Nacional de Sismógrafos del Instituto Geofísico de la Escuela Politécnica Nacional (permanent) stations. Red dashed rectangles represent the location and width of the cross sections shown on Figure 5.

For the catalog (A-D locations) the mean of the stations used to calculate the magnitude is $4.8( \pm 2.2)$. In the resulting catalog, MI ranges from 1.2 to 6.0 (Figure S1; largest event in the Nazca oceanic crust: 11 Nov 2011Figure 3) with a mean of $2.38( \pm 0.43)$ and a magnitude of completeness of 2.1 (method of maximum curvature, MAXC; Mignan \& Woessner, 2012). The $b$ value of 1.21 , slightly above the global value in tectonic

Table 2

Statistics on Quality Class of the OSISEC Catalog (2,439 Events of A, B, C, and D Quality)

\begin{tabular}{lcccccc}
\hline Class & Event Nb & $\begin{array}{c}P \text { phases } \\
A \text { and STD }\end{array}$ & $\begin{array}{c}\text { S phases } \\
A \pm \text { STD }\end{array}$ & $\begin{array}{c}\text { ex }(\mathrm{km}) \\
A \pm \text { STD }\end{array}$ & $\begin{array}{c}\text { ey }(\mathrm{km}) \\
A \pm \text { STD }\end{array}$ & $\begin{array}{c}\text { ez }(\mathrm{km}) \\
A \pm \text { STD }\end{array}$ \\
\hline A & 131 & $6.1 \pm 1.6$ & $2.9 \pm 1.2$ & $0.24 \pm 0.10$ & $0.25 \pm 0.07$ & $0.50 \pm 0.13$ \\
B & 437 & $6.0 \pm 2.0$ & $2.7 \pm 1.3$ & $0.34 \pm 0.20$ & $0.32 \pm 0.13$ & $0.87 \pm 0.34$ \\
C & 934 & $6.3 \pm 2.0$ & $3.0 \pm 1.4$ & $0.66 \pm 0.44$ & $0.41 \pm 0.25$ & $0.94 \pm 0.62$ \\
D & 937 & $5.8 \pm 1.9$ & $2.5 \pm 1.4$ & $0.87 \pm 0.58$ & $0.74 \pm 0.49$ & $1.10 \pm 0.80$ \\
\hline
\end{tabular}

Note. $A$ and STD stand for average and standard deviation. $P$ and $S$ phases represent the number of $P$ and $S$ phases; $e x, e y$, and $e z$ are the $\mathrm{E}-\mathrm{W}, \mathrm{N}-\mathrm{S}$, and vertical uncertainty (in kilometers), respectively. 


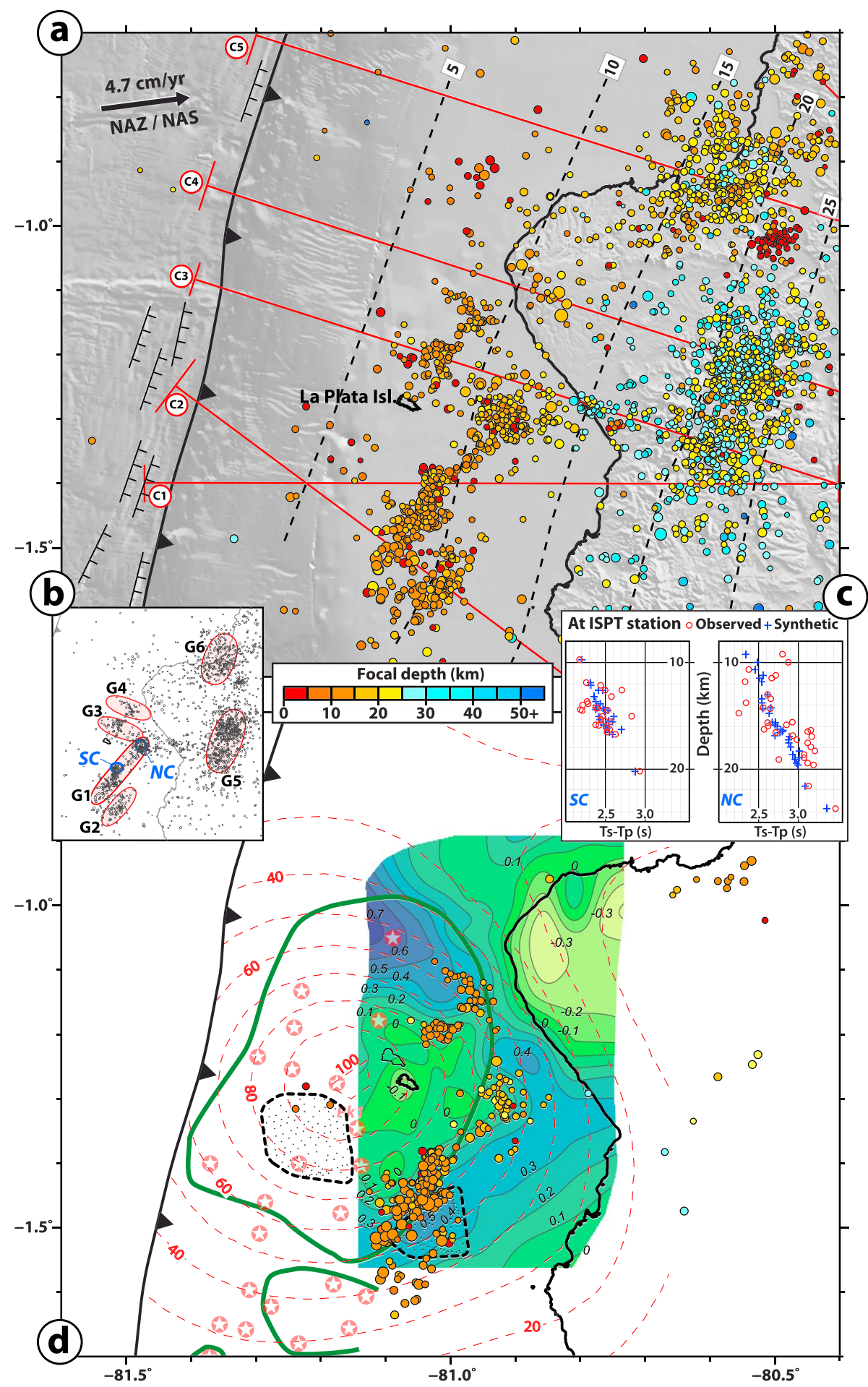

Figure 4. Seismicity distribution (same location process than Figure 2; 1,500 events of quality A, B, and C) centered on La Plata Island. (a) Catalog from June 2011 to January 2013. Red lines locate the cross sections shown in Figure 6. Red brackets at their termination indicate the cross-section width. Dashed black lines represent the isodepth contours of the top of the Nazca Plate inferred from this study (in kilometers). (b) Cluster names referred in the text. Blue ellipses indicate the southern and northern narrow clusters used in c; (c) Inset showing the good correlation between theoretical (blue) and observed (red) $S$ minus $P$ traveltimes at La Plata station for two small subset of events located offshore (SC and NC in b). (d) Catalog from 15 to 25 January 2013 showing the earthquake swarm concomitant with a slow-slip event. The slow-slip rupture zone is shown with thick black lines and dotted area (Segovia et al., 2015). The green to blue color map and associated thin gray contours shows the tectonic subsidence of the continental shelf (subsidence is positive; Proust et al., 2016). The thick green line marks the contour of an oceanic relief subducting at depth (Collot et al., 2017). The white stars represent Nazca basement peaks observed from multichannel seismic and the dashed red contour line represent interseismic coupling coefficient both from Collot et al. (2017). 


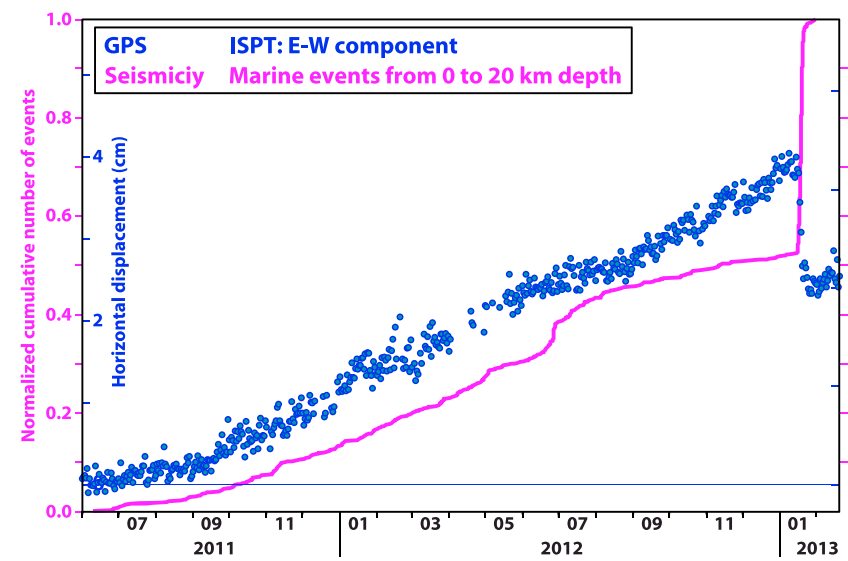

Figure 5. GPS time series at La Plata station (E-W component, blue dots) and normalized seismic rate based on superficial (0- to 20-km depth) offshore events (pink curve) areas (Frolich \& Davis, 1993), is reflecting a larger proportion of earthquakes with small magnitudes against higher magnitudes during the observation period.

\subsection{Focal Mechanisms}

To determine focal mechanisms, we used the FOCMEC software (Snoke, 2009). This code performs a systematic search of the focal sphere to find the double couple solutions compatible with the polarity and amplitude ratio data. In our study, we used $P, S V$, and $S H$ polarities and $S V / S H$ ratios. $S V / P, S H / P$ ratios were not computed since attenuation laws are not well known for the coastal region of Ecuador. We determine 49 focal mechanisms for quality location events $A, B$, and $C$, with 8 to $15 P, 1$ to $4 S V, 1$ to 4 $\mathrm{SH}$ polarities, and 1 to $3 \mathrm{SV} / \mathrm{SH}$ ratios, while searching for the best strike and dip with a step size of $5^{\circ}$.

We discard all results that show one or more errors in polarity. The remaining 38 focal mechanisms were categorized into three groups according to the strike and dip variation of the nodal planes solutions: dip variations lower than $5^{\circ}$, between $5^{\circ}$ and $20^{\circ}$, and between $20^{\circ}$ and $30^{\circ}$ for groups $A, B$, and $C$, respectively (Figure S2). We ended with 13, 8, and 17, focal mechanisms of quality A, B, and C (Figure 3 and Table S2).

\section{Results Analysis}

The local densification of the seismological network in the study area yielded a thirtyfold increase of the number of seismic detections in the area compared to the seismic catalog of the RENSIG over the same period of time. The completeness threshold magnitude decreased from magnitude 3.6 for RENSIG catalog to 2.1 for the OSISEC temporary network catalog (Figure S1). The earthquake location process using specific 1D gradient velocity models yields a higher precision hypocenter catalog. Consequently, the microseismicity to moderate seismicity recorded provides a refined and unprecedented picture of the active deformation during this period that was never previously achieved in the area (Figure 4).

This seismicity exhibits well-gathered clusters of different sizes, shapes or depths that are surrounded by quiescent regions characterized by very little seismic activity. From the catalog generated between June 2011 and January 2013 for the whole study area, 80\% of earthquakes arise as background seismicity, and $20 \%$ are associated with offshore swarms, following the definition of Holtkamp and Brudzinski (2011), that is, an increase of the seismicity rate above the background rate without a clear triggering mainshock earthquake. The first swarm occurred in June 2012 and produced only 2\% of the events (largest event of magnitude 4.7). The second lasted 1 week and consists of $\sim 18 \%$ of all events, that is, almost $50 \%$ of the offshore seismicity (Figure 5). It occurred in January 2013 as an abrupt increase in the seismicity rate without any mainshock, with the largest earthquake (magnitude 4.5) occurring in the middle of the sequence, as often observed during a seismic swarm (Holtkamp et al., 2011). Simultaneously, a sudden and large change of direction and rate motion is observed on the times series of seven GPS stations (only ISPT E-W component is shown on Figure 5). This signal is explained by the occurrence of a SSE on the plate interface (Segovia et al., 2015). The kinematic inversion of GPS times series leads to a model of a sequence of two rupture patches along the interface (Segovia et al., 2015; shown in Figures 4 and 7). The second and shallower patch releases about $80 \%$ of the total moment estimated from geodetic motion $(3.62 \mathrm{E}+18 \mathrm{~N} \cdot \mathrm{m}$ or equivalent magnitude $M w^{\prime}=6.3$ ). The 2013 seismic swarm was synchronous with that second patch of the SSE sequence.

\subsection{Determining Geometry of the Subduction Megathrust}

Because the shape of the subduction megathrust is a key to understand the subduction processes and the seismogenesis, we first evaluated the geometry and depth of the subduction megathrust based on the distribution of hypocenters and focal mechanisms, assuming that thrust mechanisms compatible with global plate motion will concentrate near the subduction megathrust. This determination is complicated by the discontinuous pattern of the seismicity along the megathrust and by the uncertainties on the hypocenter depth $( \pm 3 \mathrm{~km})$. Fortunately, the E-W refraction profile shot across the trench and the continental slope (Graindorge et al., 2004) provides a good constraint on the position of the subduction interface and intersects the main 


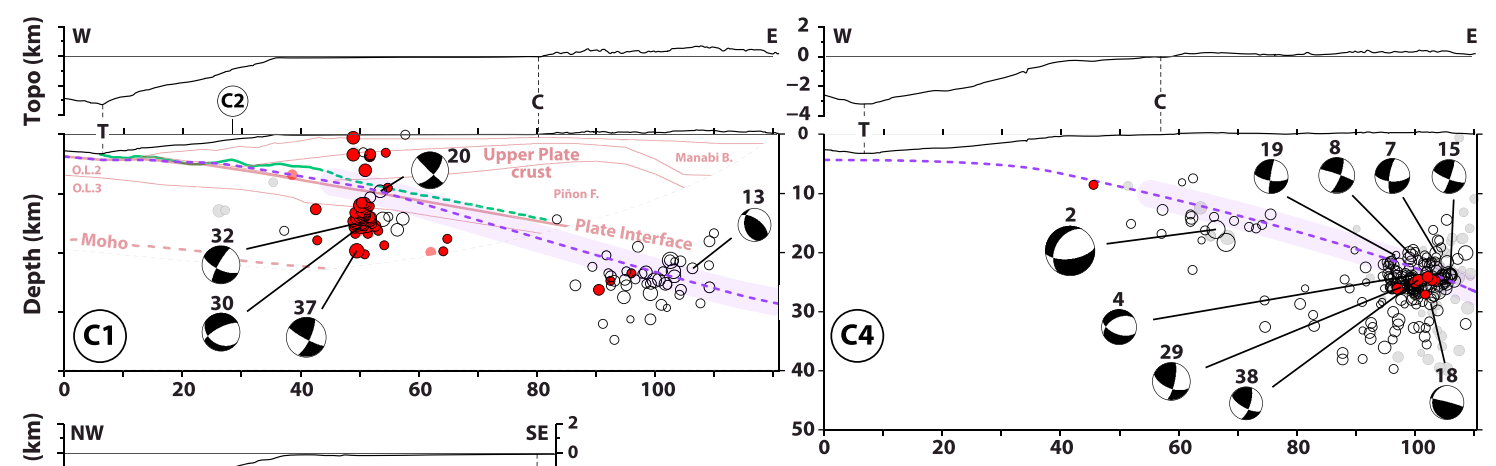

Earthquake location quality Interplate contact zone

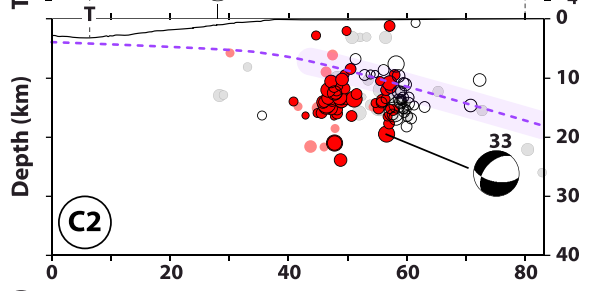

Background seismicity

OA-C D

2013 swarm (SSE)

A-C D

-... This study

+/- $3 \mathrm{~km}$ uncertainty

After Graindorge et al., 2004

_ After Collot et al., 2017
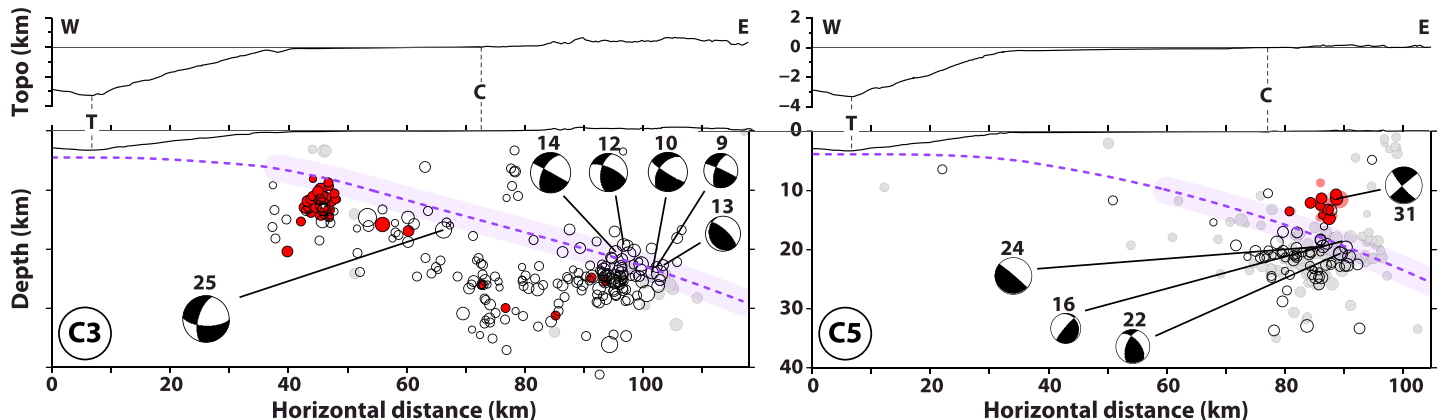

Figure 6. Example of seismic cross sections: The purple dashed line represents the interplate contact zone and the purple shaded area the associated uncertainty range $( \pm 3 \mathrm{~km})$. Location map and widths are shown in Figures 2 and 4. Seismicity before the slow-slip event (SSE; January 2013) is shown in black and during SSE in red (light red and light black circles are D quality earthquakes). Focal mechanisms are shown in cross section. T marks the trench and C the coastline. Cross section C1 parallels a wide-angle section: The interpretation of the major lithospheric layers inferred from seismic refraction line in red is from Graindorge et al. (2004). The alternate geometry of the interplate in green is from Collot et al. (2017).

$\mathrm{N} 40^{\circ} \mathrm{E}$ offshore seismic alignment (G1 in Figure $4 \mathrm{~b}$ ) as well as the southern edge of the deeper cluster (G5 in Figures 4 and $6 \mathrm{C} 1$ ). The top of the subducting plate inferred from the modeling of wide-angle seismic data is at 10-km depth (Graindorge et al., 2004), that is, $\sim 2 \mathrm{~km}$ above the seismic cluster, which is located in the crust of the subducting Nazca plate (at $50 \mathrm{~km}$ from the trench, Figure 6C1). The top of the Nazca Plate from the joint inversion of vertical multichannel and wide-angle seismic data is even slightly shallower (Collot et al., 2017, in green in Figure 6C1). Assuming that there is no major lateral discontinuity in the subduction megathrust, the analysis of the seismicity distribution leads us to consider that the other shallow seismic clusters located offshore are likely located near the subduction interface and within the subducting Nazca crust (Figure 6C2: between 45 and 60 km; Figure 6C3: between 40 and 50 km).

In order to define the position and geometry of the deeper part of the subduction megathrust we use, among others, cross sections C3, C4, and C5 (Figure 6) that intersect the Coastal Range clusters at depths between $\sim 20$ and $30 \mathrm{~km}$ (G5 and G6 in Figure 4b). These clusters exhibit nine thrust focal mechanisms compatible with a shallow-dipping subduction interface, that is, with nodal planes with angles ranging between $15^{\circ}$ and $25^{\circ}$ consistent with the subduction angle, and $P$ axes consistent with the convergence direction (mechanisms 9 , 10,12 , and 14 on section $C 3 ; 7,8,15$, and 19 on section C4; and 31 on section C5, Figure 6). We interpolate the position of the subduction megathrust through the group of subduction-like thrust mechanisms rather than the zone of higher density of the seismic cluster located 3-4 km deeper. 


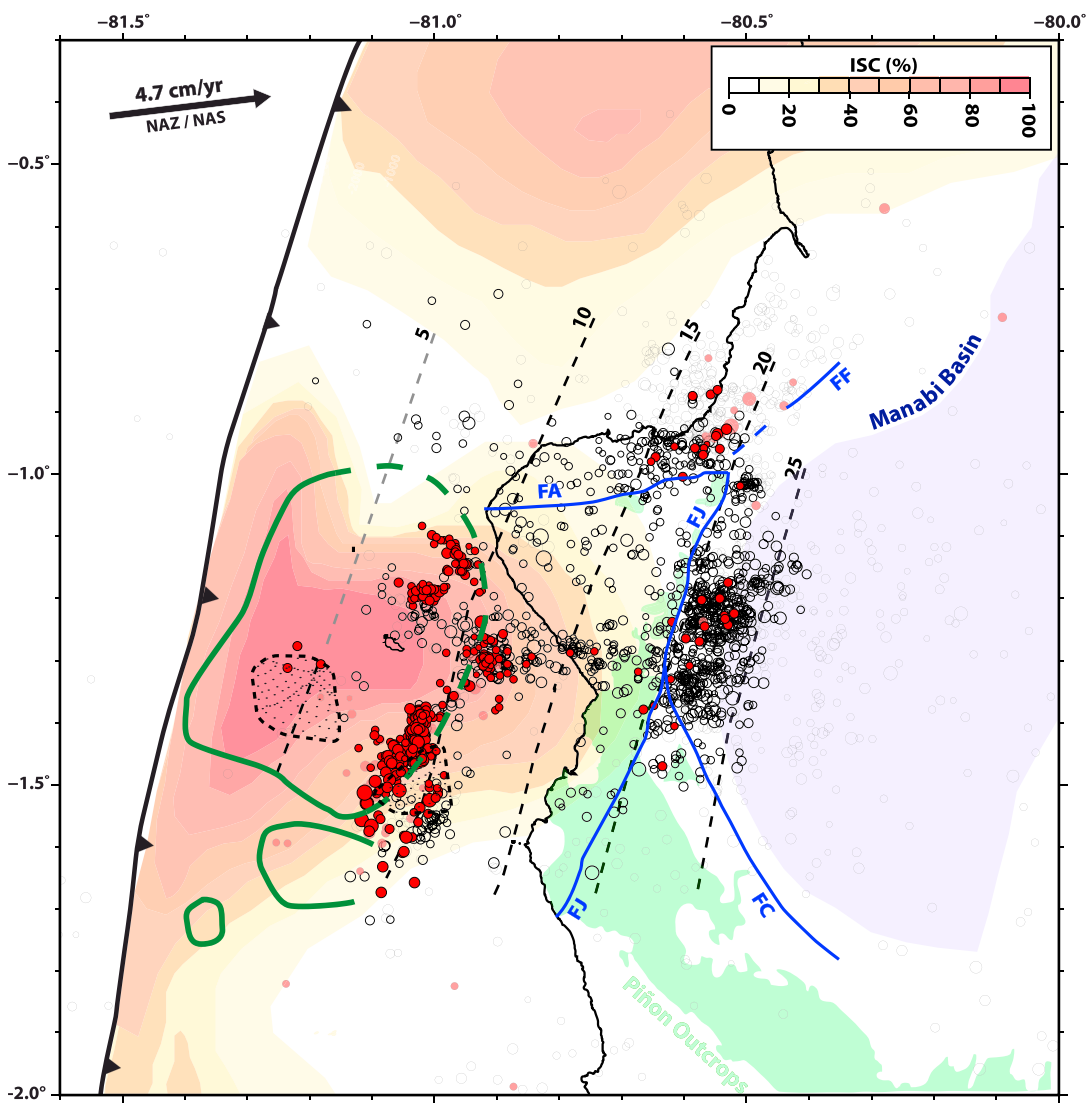

Figure 7. Seismic segmentation in the Central Ecuadorian subduction zone and its relation with the seismic coupling (Nocquet et al., 2014) and upper plate geology (Reyes \& Michaud, 2012). Fault zones: FF: Flavio Alfaro fault; FA: El Aromo fault; FJ: Jipijapa fault; FC: Cascol fault. The green shaded area represents the site where the dense Piñon formation outcrops. The blue shaded area highlights the sedimentary forearc basins. The thick green line marks the shallow limit of the subducting oceanic relief (Collot et al., 2017). The slow-slip rupture zone (January 2013) is shown with thick black lines and dotted area (Segovia et al., 2015). Red circles are earthquakes occurring during the slow-slip event, black ones represent the background seismicity. Depth of earthquakes is referenced in Figures 4 and 6 . ISC $=$ interseismic coupling.

We thus obtain a first-order image of the geometry and depth of the subduction megathrust, with a dip angle reaching $16^{\circ}$ at depth. This image is compatible with models based on seismic data (at depth lower than $\sim 10 \mathrm{~km}$ ) and with the distribution of seismic activity found in this study.

\subsection{Seismic Clusters and Alignments}

The seismic activity in the marine forearc appears in map view as well-defined, narrow ( $\sim 5$ to $10 \mathrm{~km})$ and elongated clusters (Figures 4 and 7 ) between $1.6^{\circ} \mathrm{S}$ and $1.1^{\circ} \mathrm{S}$. Two of them strike N40 (G1 and G2, Figure $4 \mathrm{~b}$ ) and two other, less defined clusters, strike $\mathrm{N} 110^{\circ}$ (G3 and $\mathrm{G} 4$ ). In cross sections, these clusters are elongated subvertically, from $\sim 10$ - to $\sim 22-\mathrm{km}$ depth (Figure 6 ), affecting mostly the oceanic crust of the subducting plate (according to our interplate boundary model and available wide-angle data). In order to test the actual vertical dispersion of hypocenters, we compare theoretical and observed time delay between $P$ and $S$ waves at the station ISPT for two groups of epicenters included in a $\sim 2$-km-radius along the major alignment (Figures $4 \mathrm{~b}$ and $4 \mathrm{~d}$ ). The good agreement between theoretical and observed time delay and the quasi-linear relation with depth confirm the depth distribution over a $\sim 10-\mathrm{km}$ vertical extension.

These seismic alignments correspond to the 1 week long swarm in January 2013 concomitant with a SSE located in this area (Segovia et al., 2015) (Figures 4 and 7). The narrowness of the alignments (in map and cross sections) and their position within the Nazca Plate support that this activity represents the reactivation of preexisting crustal faults. Associated focal mechanisms are mainly thrust type with $P$ axis directions varying mainly from SW to NW, roughly compatible with the relative plate motion (Figures 3 and 6). 
At the longitude of the Coastal Range, we observed two main seismic clusters centered respectively at latitude $1.25^{\circ} \mathrm{S}$ between 15- and 20-km depth (G5 in Figure 4) and at latitude $0.9^{\circ} \mathrm{S}$ between 20 and $25 \mathrm{~km}$ (G6). Most of the hypocenters are deeper than $20 \mathrm{~km}$ except a small and shallow cluster of earthquakes located at the western end of the crustal El Aromo fault at $1.05^{\circ} \mathrm{S}$ (Figures 4 and 7 ). Most of the deep events have thrust mechanisms compatible with the plate motion (Figures 3 and 6).

\section{Discussion}

\subsection{Geometry of the Interplate Fault}

We defined the geometry of the interplate fault using available seismic constraints near the surficial portion of the plate interface using a smooth interpolation through the hypocenters of thrust events at depths greater than $20 \mathrm{~km}$. Since the depth uncertainty is $\pm 3 \mathrm{~km}$ for the hypocenters and the interplate fault could have been interpolated passing through the entire set of hypocenters, the dip angle of the plate between 30 and $90 \mathrm{~km}$ east of the trench ranges between $16^{\circ}$ and $20^{\circ}$. These values are consistently larger than those found closer to the trench (between 0 - and 10-km depth) ranging from $6^{\circ}$ to $10^{\circ}$ (Collot et al., 2017; Graindorge et al., 2004; Sage et al., 2006), and smaller than those found eastward (between 25- and 200$\mathrm{km}$ depth) ranging from $25^{\circ}$ to $35^{\circ}$ for Central Ecuador (Font et al., 2013; Guillier et al., 2001; Prévot et al., 1996). The dip angle found in this study is then consistent with a progressive steepening of the dip angle from $6^{\circ}$ to $25^{\circ}$ related to the flexure of the plate.

Comparatively, north of the Carnegie Ridge, the top of the Nazca plate dips from $10^{\circ}$ near the trench to 25$30^{\circ}$ at depths ranging from 30 to $140 \mathrm{~km}$ (García-Cano, 2009; Manchuel et al., 2011; Pontoise \& Monfret, 2004). In northwestern Peru, the plate is plunging with an angle of $10^{\circ}$ from the trench to beneath the coast line and then it increases to $28^{\circ}$ (Tavera et al., 2006).

Despite the presence of the thickened oceanic crust of the Carnegie ridge beneath Central Ecuador, there is no evidence that the interplate fault dips with a lower angle.

\subsection{Relationship Between Local Seismicity and Seismic Coupling}

In a continental context, geodetic and seismic data revealed that major strike slip faults (e.g., the San Andreas Fault) consist of a patchwork of locked patches with little microseismicity as well as creeping zones hosting abundant small earthquakes that represent small patches of the fault that repeatedly break within aseismically slipping areas (Bürgmann et al., 2000; Simpson et al., 2001). There, the largest concentrations of microearthquakes are found at transition zones between locked and more freely slipping regions. Similar patterns are observed at subduction zones with abundant microseismicity occurring at the transition zone between a locked zone (with no microseismicity) and a creeping zone as described in Costa Rica, northeast Japan, Kuril, Alaska, and the Himalayas (Avouac, 2015; Igarashi et al., 2003; Schwartz \& DeShon, 2007; Takahashi \& Kasahara, 2007).

The small coupled patch (near La Plata Island) is entirely covered by the OSISEC network. In this area, the earthquake location uncertainties are low (Table 2) providing an unprecedented, ,detailed and well-focused image of the seismicity for magnitudes as low as 2.1 .

Onshore, the activity observed during the whole recording period is distributed along two distinct clusters at depths greater than $15 \mathrm{~km}$ (Figures 4 and 6). The seismicity occurs near the interface between the two plates and/or within the downgoing plate. The main cluster is located between -1.0 and $-1.5^{\circ}$ at depths greater than $20 \mathrm{~km}$ (G5 on Figure $4 \mathrm{~b})$. The northern cluster $\left(\sim 0.9^{\circ} \mathrm{S}\right)$ is slightly shallower, mostly between 15 and $20 \mathrm{~km}$ (G6 on Figure 4b), and is separated from the southern cluster by a narrow E-W corridor showing a lack of seismicity. Both clusters at the interface and in the upper part of the downgoing plate outline the transition zone between the shallow locked portion of the interplate (ISC coefficient higher than 20\%) and the deep stable creeping one (Figures 4 and 6: cross sections C3, C4, and C5).

In map view, these clusters further appear linked to known regional crustal faults. The $\mathrm{N} 30^{\circ}$ striking Jipijapa fault and the $\mathrm{N} 150^{\circ}$ striking Cascol Fault separate the uplifted basement of the NAS to the west (i.e., the dense Piñón and Cayo outcrops, Figure 7) from the sedimentary basin of Manabí to the east (Reyes, 2013; Reyes \& Michaud, 2012). The surface traces of these faults clearly coincide with the westward and southward extension of the G5 deeper cluster, which is located beneath the westernmost part of the sedimentary basin 
(Figure 7). To the north, the N90 ${ }^{\circ}$ trending El Aromo fault (Reyes, 2013; Reyes \& Michaud, 2012) correlates with the southern extension of the northern G6 cluster (Figure 7). In both cases, the structural organization of the upper plate apparently influences the occurrence of the seismicity at depths larger than $20 \mathrm{~km}$ (near the plate interface).

In various subduction zones, the ISC and the location of interplate seismicity have been related to the upper plate structure. In northern Chile this coupling and seismic segmentation correlates with the presence of a crustal-scale fault structure in the overriding plate that changes the frictional properties at depth along the subduction megathrust (Béjar-Pizarro et al., 2013). In the Lesser Antilles, interplate seismicity is correlated to old and dense crustal material possibly related to the Caribbean oceanic plateau (Ruiz et al., 2011). The authors suggest that the weight of the forearc wedge column imposes a vertical stress on the interplate fault zone, diminishing (inhibiting) the seismicity, and that, therefore, the structural and lithological spatial changes of the forearc wedge along the margin could influence the distribution of the seismicity. In New Zealand, the geology (e.g., age of the terranes) seems to control the interplate coupling relating this with the impermeability of the terranes. Where the terrane is impervious, the coupling is high and fluids are redirected along the interface plane changing its property to a conditionally stable and favoring the seismicity (Reyners \& Eberhart-Phillips, 2009).

Our results about the deeper seismicity show a clear spatial correlation with the geology of the upper plate. Rheological boundaries implying strong density contrasts associated to crustal faults (Jipijapa fault delimiting the thick sedimentary Manabi Basin to the east from the dense and outcropping Piñon basement to the west) are likely to interact with the interplate boundary controlling the downdip extension of the locked patch in one hand, and increasing the seismic activity locally through the input of fluids along the Jipijapa fault in the other hand.

\subsection{Relationship Between Offshore Seismicity and the Subduction of an Oceanic Relief}

Offshore, most of the seismic activity occurred during a single episode (Figure 7) that coincides in time with a SSE detected by geodetic measurements in January 2013 (Figure 5; Collot et al., 2017; Segovia et al., 2015). The largest earthquake observed during this episode had a magnitude of 4.5 . In the following, we will discuss the hypocentral distribution of the seismicity in the tectonic framework and its relation to seismic coupling.

The seismicity is organized in narrow and elongated clusters that trend $\mathrm{N} 40^{\circ}$ (south and east of La Plata Island) and $\sim \mathrm{N} 110^{\circ}$ (north of the island between 10- and 15-km depth). When comparing to the different ISC models, the seismicity occurs preferentially in zones with an ISC ranging from 50 to $80 \%$ (Figure 7; Chlieh et al., 2014; Collot et al., 2017; Nocquet et al., 2014).

The observed quiescence near the trench is consistent with the strongly coupled patch described around La Plata Island. According to Proust et al. (2016) and Collot et al. (2017) this patch is tied to the subduction of a 1.5-to-2 km high, $50 \times 40 \mathrm{~km}$ wide, oceanic relief that belongs to the Carnegie Ridge. Near the trench, the extension of the oceanic relief is based on the modeling of seismic data (Collot et al., 2017), whereas to the east, the location of the flank of the oceanic relief is mostly estimated from a detailed stratigraphic analysis of the sedimentary sequence deposited on top of the shelf (Proust et al., 2016). The authors assume that the transition between the recently (less than $14 \mathrm{kyr}$ ) uplifted and subsided portions of the overriding margin basement spatially coincides with the frontal slope of the oceanic relief at depth (Proust et al., 2016). On a map view, the shape of the uplifted plateau is almost rectangular, with the highest relief emerging at La Plata Island (green shaded on Figure 4). The strong gradient from the uplifted plateau to the largest value of subsidence (blue shaded on Figure 4) would mark the frontal slope of the oceanic relief, trending $\mathrm{N} 110^{\circ}$ on the northern edge of the plateau and $\mathrm{N}^{\circ} 0^{\circ}$ on the southern edge. We observe that the offshore seismic swarms outline the boundary of the uplifted basement described by Proust et al. (2016), trending N110 ${ }^{\circ}$ to the north of La Plata Island and $\mathrm{N} 40^{\circ}$ to the south. This spatial correlation attests to the relationship between the location of the seismicity and the leading edge of the subducting oceanic relief.

We observed very little seismicity in the upper plate unlike prior observations in this area, which exhibit earthquakes affecting the basement of the upper plate East of La Plata Island (Béthoux et al., 2011; Font et al., 2013). This difference could be due either to the timing and the duration of the observation, or to the lack of precision of the depth determination in previous datasets. During the OSISEC experiment, very few isolated earthquakes affect the overriding margin (Figure 4), except a few events gathered on the Manta 


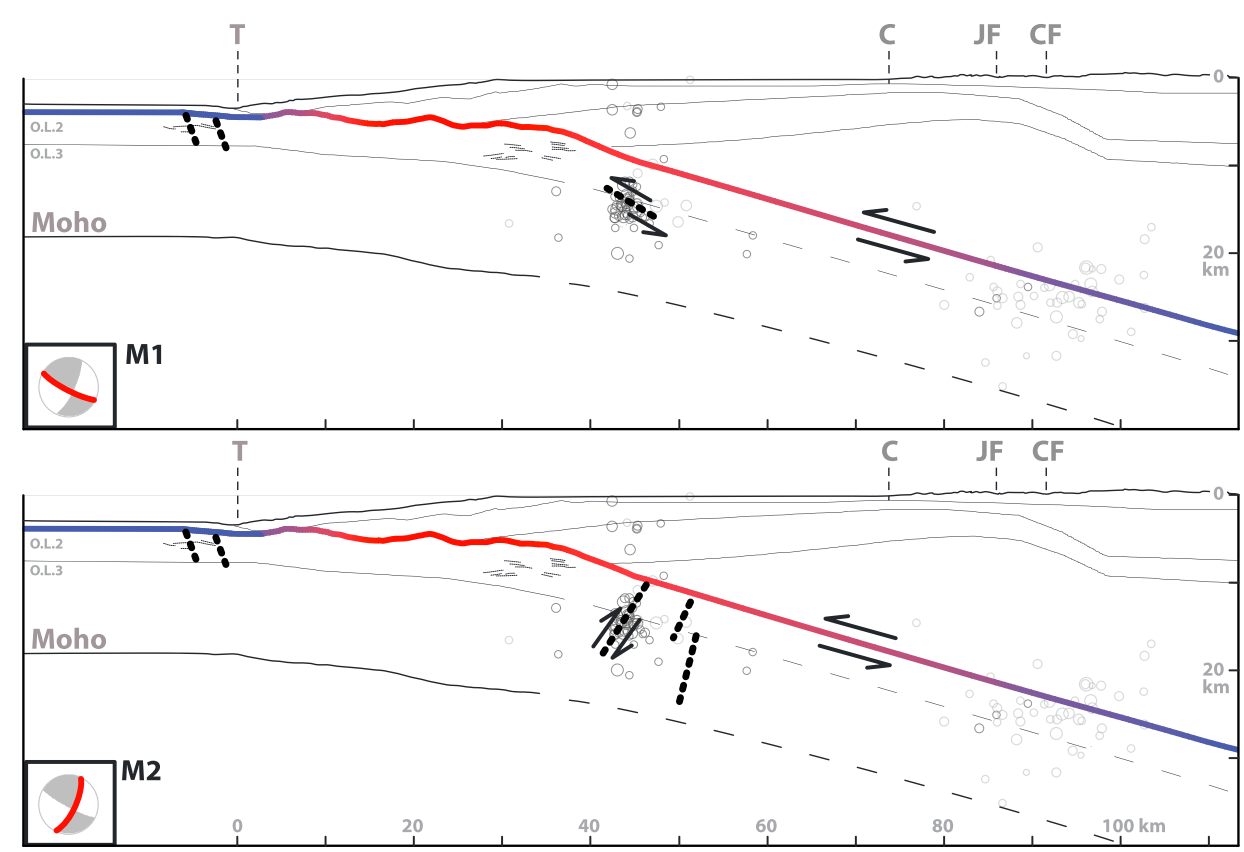

Figure 8. Schematic diagram showing two possible interpretations discussed in the text with respect to the earthquakes position and focal mechanism parameters. Models are not exclusive and not necessarily competing. Slow-slip rupture is not represented. Lithospheric structures and deep reflectors position (discontinuous thin lines within oceanic layer 2) are derived from wide-angle profile interpretations of Collot et al. (2017). O.I.2, O.I.3 stand for oceanic layers 2 and 3 (Graindorge et al., 2004). The interseismic coupling variation is represented from red (highly coupled) to blue (uncoupled) along the interplate. T: Trench; C: Coastline; JF: Jipijapa fault trace; CF: Cascol fault trace; M1: Favoring a low-angle thrust activity within the crust of the downgoing plate; M2: Favoring the reactivation of preexisting faults zone within the crust of the downgoing plate (preferred model).

Peninsula (Figure 6C3) which contrast with the current idea that the margin crust is pervasively fractured above the oceanic relief. If the subduction of the oceanic relief actively deforms the margin crust (Collot et al., 2017), the process appears aseismic during the observation period.

Instead, during the period of observation, the seismically active deformation concentrates almost exclusively in the crust of the Nazca plate at the leading edge of the oceanic relief. This seismicity is synchronous with the 2013-SSE (Collot et al., 2017; Segovia et al., 2015).

In cross sections, the hypocenters of offshore events are distributed in the upper oceanic crust (oceanic layer 2) of the subducting Nazca Plate (Sallarès et al., 2005), as subvertical elongated clusters (Figure 6). Focal mechanisms are consistent with the compressive regime related to plate convergence (Figure 3 ). The events $20,37,32,36$, and 33 are thrust with a nodal plane striking $\mathrm{N}-\mathrm{S} \pm 10^{\circ}$. The average dip angle of the subvertical nodal planes is $60^{\circ} \pm 5^{\circ}$, compatible with the westward dipping fault zone described by the hypocentral distribution. The average dip angle of the subhorizontal nodal plan is $39^{\circ} \pm 12^{\circ}$, which is about $20^{\circ}$ higher than the eastward dipping subduction plane.

We propose two, nonexclusive, tectonic interpretations for the shallow offshore seismicity observed around La Plata Island.

If the subhorizontal nodal plane is the active one, these events could be located along a newly forming gentle thrust located within the upper oceanic crust (M1, Figure 8). In this interpretation, the thrust position could be correlated with the deep seismic reflectors, parallel to the plate interface, observed on seismic lines beneath the subducting oceanic relief, in oceanic layer 2, and interpreted as evidence of the internal shearing of the subducting relief (Collot et al., 2017). These authors propose that those deep reflectors could image the site of crustal shearing that could contribute to distributing the volume anomaly of the resistant subducting relief over a wider area. On the contrary, if the subvertical nodal plane is the active one, it implies that preexisting faults affecting the oceanic crust (i.e., possibly bending faults) are reactivated either in the local stress field due to the SSE or in the regional stress regime (M2, Figure 8). 
These two hypotheses are not competing and seismic events can occur on all both types of faults. However, as this shallow offshore seismicity is only observed at the downdip edge of the oceanic relief (section C1, C2, and $\mathrm{C} 3$ in Figures 4 and 6), it suggests a causal relationship between the two. After the shape of the seismic cluster in cross section (Figure 6), and because the edge of the relief is likely a weak zone more easily affected by faulting during the bending phase, we would favor the second interpretation to explain the distribution of hypocenters located inside the Nazca crust.

Several seismic swarms have been detected in this area in 1977, 1993, 1998, 2002, 2005, 2010, and 2013 (Font et al., 2013; Holtkamp et al., 2011; Segovia, 2001; Segovia et al., 2015; Vaca et al., 2009; Vallée et al., 2013) lasting between a few days to a month. With geodetic instrumentation of the Ecuadorian coast, the last three swarms could be related to shallow SSEs (Segovia et al., 2015; Vallée et al., 2013). As suggested by Vallée et al. (2013), seismic swarms in this area most probably represents the occurrence of SSE.

During the 2010 SSE (Vallée et al., 2013), the microseismicity is located in the immediate vicinity or within the aseismic rupture zone at a depth of 7 to $12 \mathrm{~km}$, most of them being in the crust of the subducting oceanic relief (Collot et al., 2017). The distribution of this seismicity coincides in map view with cluster G3 (Figure 4b). Similarly, from the dense offshore-onshore seismic array, we show that the 2013 SSE is accompanied by a synchronous seismic swarm that reactivates crustal faults within the downgoing plate, off of the main fault (i.e., the interplate). As most of the seismicity located offshore is related to past SSEs (see historic above), it is likely that most of the background seismicity is made up of the sum of the SSE-triggered seismicity over several SSE cycles. In this study $50 \%$ of the offshore seismicity is triggered by one large SSE. It is possible we do not detect nor identify geodetically small SSEs that account for the remaining seismic activity. Seismicity is found to have occurred outside the SSE slip zone, up to $30 \mathrm{~km}$ away to the north of the main SSE patch (Figure 4). This suggests that moderate SSE, with an equivalent magnitude ranging from 6.0 to 6.3 , affecting the interplate could possibly reactivate secondary faults in the crust of the subducting plate and not only along the main thrust. This interpretation contrasts with previous results showing SSE induced seismicity located on the plate interface (e.g., in New Zealand, Delahaye et al., 2009, or in Ecuador, Vallée et al., 2013).

At depth, the subducting oceanic relief is topped by basement peaks (Collot et al., 2017) that are inferred to locally increase the ISC, thus contributing to locking the plate interface. SSEs near La Plata Island may affect transitional friction areas interspersed between these small-scale highly coupled patches. The 2013 SSE may have propagated inside the long-term damaged zone associated with the interface in between the peaks of the oceanic relief. The relief is inferred from seismic reflection imaging, which are assumed to locally increase the ISC, thus contributing to the locking of the plate interface (Collot et al., 2017). In the area where basement peaks are observed (white-red stars in Figure 4), no seismicity was detected near the plate interface suggesting that it did not rupture at the peak locations where stress accumulates.

Although the subducting oceanic relief described in Collot et al. (2017) is part of the Carnegie Ridge, the behavior of this area is clearly different from the behavior of the bulk of the subducting Carnegie Ridge elsewhere. The subduction interface in the study area is locked, with recurrent SSE releasing at least part of the accumulated stress, whereas other segments of the Carnegie Ridge coincides with an unlocked, creeping, subduction interface (Chlieh et al., 2014). These observations suggest that the small 50-km diameter seamount has a strong impact on the locking of the subduction interface (Collot et al., 2017).

\section{Conclusions}

Results from the OSISEC experiment provide a precise view of the seismicity around the discrete and highly coupled patch of La Plata Island with a magnitude of completeness as low as 2.1.

The first-order geometry of the subduction slab appears as a two-dimensional curvature with a dip angle increasing from $\sim 6^{\circ}$ near the trench to $16-20^{\circ}$ beneath the Coastal Range and up to $25-30^{\circ}$ at depth.

The La Plata locked patch is limited to the north by a narrow creeping zone with a low-to-null seismic rate which may have acted as a persistent barrier to large historical seismic ruptures, including the most recent, 16 April 2016, Mw = 7.8, Pedernales earthquake. The locked patch is limited to the south by a major creeping zone characterized by the lack of microseismicity. 
At depth $(\sim 20 \mathrm{~km})$, the seismicity marks the down-dip extension of the locked area that also spatially coincides with the crustal fault system that separates the Manabí sedimentary Basin to the east from the uplifting Manta-La Plata area. It is likely a major rheological boundary of the overriding basement, which controls changes in the frictional properties at depth along the subduction megathrust as has been suggested in the Mejillones Peninsula (Chile; Béjar-Pizarro et al., 2013). Therefore, the changes in the nature and rheology of the overriding basement could partly control the downdip extension of the locked patch and influence the location of the deep microseismicity.

In January 2013, a seismic swarm in the marine forearc accompanied a SSE. While this type of seismicity is generally assumed to be located along the subduction megathrust which undergo SSEs, we here provide evidence that the seismicity is related to the activation of secondary faults located within the crust of the subducting plate. Those crustal faults mark the leading edge of a subducting oceanic relief, which contribute to the locking of the subduction megathrust.

\section{Acknowledgments}

We are grateful to John Geissman (Editor Tectonics) and an anonymous reviewer for helpful review of the early version of this manuscript and to Nicholas Stewart for proofreading. We thank SENESCYT (Secretaría Nacional de Educación Superior, Ciencia, Tecnología e Innovación) and the French Embassy in Quito for MS PhD scholarship; SENACYT (Secretaría Nacional de Ciencia y Tecnología) with the project "PIN-08EPNGEO-00001: Fortalecimiento Del Instituto Geofisico" for funding the broadband seismic stations and their deployment on-land; IRD and INSU (CNRS) for funding the OBS deployments. The French National Research Agency also supported this work through the project REMAKE (grant ANR-15-CE04-004). INOCAR provides ship time and facilities the multiple OBS deployments and recoveries. We are greatly indebted to the Officers and crews of the R/V Orion for their professionalism and for providing operational assistance. This work is framed by the Laboratoire Mixte International "Séismes et Volcans dans les Andes du Nord" of IRD. The seismic data used in this study are archived at the Instituto Geofisico de la Escuela Politécnica Nacional and can be requested from "http://www.igepn.edu. ec/contactenos."

\section{References}

Avouac, J.-P. (2015). From geodetic imaging of seismic and aseismic fault slip to dynamic modeling of the seismic cycle. Annual Review of Earth and Planetary Sciences, 43(1), 233-271. https://doi.org/10.1146/annurev-earth-060614-105302

Beck, S. L., \& Ruff, L. J. (1984). The rupture process of the Great 1979 Colombia Earthquake: Evidence for the asperity model. Journal of Geophysical Research, 89(B11), 9281-9291. https://doi.org/10.1029/JB089iB11p09281

Béjar-Pizarro, M., Socquet, A., Armijo, R., Carrizo, D., Genrich, J., \& Simons, M. (2013). Andean structural control on interseismic coupling in the North Chile subduction zone. Nature Geoscience, 6(6), 462-467. https://doi.org/10.1038/ngeo1802

Béthoux, N., Segovia, M., Alvarez, V., Collot, J. Y., Charvis, P., Gailler, A., \& Monfret, T. (2011). Seismological study of the central Ecuadorian margin: Evidence of upper plate deformation. Journal of South American Earth Sciences, 31(1), 139-152. https://doi.org/10.1016/j. jsames.2010.08.001

Billings, S. D., Sambridge, M. S., \& Kennett, B. L. N. (1994). Errors in hypocenter location: Picking, model and magnitude dependence. Bulletin of the Seismological Society of America, 84(6), 1978-1990.

Bürgmann, R., Schmidt, D., Nadeau, R. M., d'Alesio, M., Fielding, E., Manaker, D., et al. (2000). Earthquake potential along the northern Hayward fault, California. Science, 289(5482), 1178-1182. https://doi.org/10.1126/science.289.5482.1178

Castagna, J. P., Batzle, M. L., \& Eastwood, R. L. (1985). Relationships between compressional-wave and shear-wave velocities in clastic silicate rocks. Geophysics, 50(4), 571-581. https://doi.org/10.1190/1.1441933

Chlieh, M., De Chabalier, J. B., Ruegg, J. C., Armijo, R., Dmowska, R., Campos, J., \& Feigl, K. L. (2004). Crustal deformation and fault slip during the seismic cycle in the North Chile subduction zone, from GPS and InSAR observations. Geophysical Journal International, 158(2), 695-711. https://doi.org/10.1111/j.1365-246X.2004.02326.x

Chlieh, M., Mothes, P. A., Nocquet, J.-M., Jarrín, P., Charvis, P., Cisneros, D., et al. (2014). Distribution of discrete seismic asperities and aseismic slip along the Ecuadorian Megathrust. Earth Planet. Science Letters, 400, 292-301.

Collot, J., Sanclemente, E., Nocquet, J., Leprêtre, A., Ribodetti, A., Jarrin, P., et al. (2017). Subducted oceanic relief locks the shallow megathrust in central Ecuador. Journal of Geophysical Research: Solid Earth, 122, 3286-3305. https://doi.org/10.1002/2016JB013849

Collot, J.-Y., Marcaillou, B., Sage, F., Michaud, F., Agudelo, W., Charvis, P., et al. (2004). Are rupture zone limits of great subduction earthquakes controlled by upper plate structures? Evidence from multichannel seismic reflection data acquired across the northern Ecuador-southwest Colombia margin. Journal of Geophysical Research, 109, B11103. https://doi.org/10.1029/2004JB003060

Delahaye, E. J., Townend, J., Reyners, M. E., \& Rogers, G. (2009). Microseismicity but no tremor accompanying slow slip in the Hikurangi subduction zone, New Zealand. Earth Planet. Science Letters, 277(1-2), 21-28. https://doi.org/10.1016/j.epsl.2008.09.038

Dorbath, L., Cisternas, A., \& Dorbath, C. (1990). Assessment of the size of large and great historical earthquakes in Peru. Bulletin of the Seismological Society of America, 80(3), 551-576.

Dziewonski, A. M., Chou, T.-A., \& Woodhouse, J. H. (1981). Determination of earthquake source parameters from waveform data for studies of global and regional seismicity. Journal of Geophysical Research, 86, 2825-2852. https://doi.org/10.1029/JB086iB04p02825

Ekström, G., Nettles, M., \& Dziewonski, A. M. (2012). The global CMT project 2004-2010: Centroid-moment tensors for 13,017 earthquakes Physics of the Earth and Planetary Interiors, 200-201, 1-9. https://doi.org/10.1016/j.pepi.2012.04.002

Engdahl, E. R., \& Villaseñor, A. (2002). Global seismicity: 1900-1999, in W.H.K. Lee, H. Kanamori, P.C. Jennings, and C. Kisslinger (editors), International handbook of earthquake and engineering seismology, Part A (chap. 81, pp. 665-690). San Diego, CA: Academic Press. https:// doi.org/10.1016/S0074-6142(02)80244-3

Font, Y., Segovia, M., Vaca, S., \& Theunissen, T. (2013). Seismicity patterns along the Ecuadorian subduction zone: New constraints from earthquake location in a 3-D a priori velocity model. Geophysical Journal International, 193(1), 263-286. https://doi.org/10.1093/gji/ggs083

Frolich, C., \& Davis, S. (1993). Teleseismic b-values; Or much ado about 1.0. Journal of Geophysical Research, 98(B1), 631-644. https://doi.org/ $10.1029 / 92 J B 01891$

Gailler, A., Charvis, P., \& Flueh, E. R. (2007). Segmentation of the Nazca and South American plates along the Ecuador subduction zone from wide angle seismic profiles. Earth and Planetary Science Letters, 260(3-4), 444-464. https://doi.org/10.1016/j.epsl.2007.05.045

García-Cano, L. (2009). 3D seismic imaging of the subduction zone at the Colombia-Ecuadorian frontier (in French) (PhD Thesis) (214 pp.). Université de Nice-Sophia Antipolis.

Graindorge, D., Calahorrano, A., Charvis, C., Collot, J.-Y., \& Bethoux, N. (2004). Deep structures of the Ecuador convergent margin and the Carnegie Ridge, possible consequence on great earthquakes recurrence interval. Geophysical Research Letters, 31, L04603. https://doi.org/ 10.1029/2003GL018803

Guillier, B., Chatelain, J. L., Jaillard, E., Yepes, H., Poupinet, G., \& Fels, J. F. (2001). Seismological evidence on the geometry of the orogenic system in central-northern Ecuador (South America). Geophysical Research Letters, 28(19), 3749-3752. https://doi.org/10.1029/ 2001 GL013257

Hello, Y., Yates, B. A., Anglade, A., Gailler, A., \& Charvis, Ph. (2006). Hippocampe: A new versatile ocean bottom seismometer. Paper presented at EGU General Assembly 2006, European Geosciences Union, Vienna, Austria, 02-07 April 2006. 
Hirata, N., Yamada, T., Shimamura, H., Inatani, H., \& Suyehiro, K. (1983). Spatial distribution of microearthquakes beneath the Japan Trench from ocean bottom seismographic observations. Geophysical Journal International, 73(3), 653-669. https://doi.org/10.1111/ j.1365-246X.1983.tb03337.x

Holtkamp, S. G., \& Brudzinski, M. R. (2011). Earthquake swarms in circum-Pacific subduction zones. Earth Planet. Science Letters, $305,215-225$. https://doi.org/10.1016/j.epsl.2011.03.004

Holtkamp, S. G., \& Brudzinski, M. R. (2014). Megathrust earthquake swarms indicate frictional changes which delimit large earthquake ruptures. Earth Planet. Science Letters, 390, 234-243. https://doi.org/10.1016/j.epsl.2013.10.033

Holtkamp, S. G., Pritchard, M. E., \& Lohman, R. B. (2011). Earthquake swarms in South America. Geophysical Journal International, 187(1), 128-146. https://doi.org/10.1111/j.1365-246X.2011.05137.x

Husen, S., Kissling, E., \& Clinton, J. F. (2011). Local and regional minimum 1D models for earthquake location and data quality assessment in complex tectonic regions: Applications to Switzerland. Swiss Journal of Geosciences, 104(3), 455-469. https://doi.org/10.1007/ s00015-011-0071-3

Igarashi, T., Matsuzawa, T., \& Hasegawa, A. (2003). Repeating earthquakes and interplate aseismic slip in the northeastern Japan subduction zone. Journal of Geophysical Research, 108(B5), 2249. https://doi.org/10.1029/2002JB001920

Jaillard, E., Benitez, S., \& Mascle, G. H. (1997). Les déformations paléogènes de la zone d'avantarc sud-Équatorienne en relation avec l'évolution géodynamique (in French). Bulletin de la Société Géologique de France, 168, 403-412.

Jaillard, E., Lapierre, H., Ordoñez, M., Toro, J., Amortegui, A., \& Vanmelle, J. (2009). Accreted oceanic terranes in Ecuador: Southern edge of the Caribbean Plate? Geological Society, London, Special Publications, 328(1), 469-485. https://doi.org/10.1144/SP328.19

Kanamori, H., \& McNally, K. C. (1982). Variable rupture mode of the subduction along the Ecuador-Colombia coast. Bulletin of the Seismological Society of America, 72(4), 1241-1253.

Kelleher, J. A. (1972). Rupture zones of large South American earthquakes and some predictions. Journal of Geophysical Research, 77(11), 2087-2103. https://doi.org/10.1029/JB077i011p02087

Luzieux, L. D. A., Heller, F., Spikings, R., Vallejo, C. F., \& Winkler, W. (2006). Origin and Cretaceous tectonic history of the coastal Ecuadorian forearc between $1^{\circ} \mathrm{N}$ and $3^{\circ} \mathrm{S}$ : Paleomagnetic, radiometric and fossil evidence. Earth Planet. Science Letters, 249, 400-414.

Mamberti, M., Lapierre, H., Bosch, D., Jaillard, E., Ethien, R., Hernandez, J., \& Polvé, M. (2003). Accreted fragments of the late cretaceous Caribbean-Colombian Plateau in Ecuador. Lithos, 66(3-4), 173-199. https://doi.org/10.1016/S0024-4937(02)00218-9

Manchuel, K., Regnier, M., Bethoux, N., Font, Y., Sallares, V., Diaz, J., \& Yepes, H. (2011). New insights on the interseismic active deformation along the North Ecuadorian-South Colombian (NESC) margin. Tectonics, 30, TC4003. https://doi.org/10.1029/2010TC002757

Mendoza, C., \& Dewey, J. W. (1984). Seismicity associated with the great Colombia-Ecuador earthquakes of 1942, 1958 and 1979: Implications for barrier models of earthquake rupture. Bulletin of the Seismological Society of America, 74(2), 577-593.

Métois, M., Socquet, A., \& Vigny, C. (2012). Interseismic coupling, segmentation and mechanical behavior of the Central Chile subduction zone. Journal of Geophysical Research, 117, B03406. https://doi.org/10.1029/2011JB008736

Michaud, F., Collot, J.-Y., Alvarado, A., López, E., \& y el personal científico y técnico del INOCAR (2006). República del Ecuador, Batimetría y Relieve Continental, publicación IOA-CVM-02-Post. INOCAR, Guayaquil.

Mignan, A., \& Woessner, J. (2012). Estimating the magnitude of completeness for earthquake catalogs, Community Online Resource for Statistical Seismicity Analysis. https://doi.org/10.5078/corssa-00180805. Retrieved from http://www.corssa.org

Nocquet, J.-M., Jarrin, P., Vallée, M., Mothes, P. A., Grandin, R., Rolandonne, F., et al. (2016). Supercycle at the Ecuadorian subduction zone after the Pedernales earthquake. Nature Geoscience, 10(2), 145-149. https://doi.org/10.1038/NGEO2864

Nocquet, J.-M., Villegas-Lanza, J. C., Chlieh, M., Mothes, P., Rolandonne, F., Jarrín, P., et al. (2014). Motion of continental slivers and creeping subduction in the northern Andes. Nature Geoscience, 7(4), 287-291. https://doi.org/10.1038/NGEO2099

Pedoja, P., Dumont, J. F., Lamothe, M., Ortlieb, L., Collot, J.-Y., Ghaleb, B., et al. (2006). Plio-Quaternary uplift of the Manta Peninsula and La Plata Island and the subduction of the Carnegie Ridge, central coast of Ecuador. Journal of South American Earth Sciences, 22(1-2), 1-21. https://doi.org/10.1016/j.jsames.2006.08.003

Pontoise, B., \& Monfret, T. (2004). Shallow seismogenic zone detected from an offshore-onshore temporary seismic network in the Esmeraldas area (northern Ecuador). Geochemistry, Geophysics, Geosystems, 5, Q02009. https://doi.org/10.1029/2003GC00056

Prévot, R., Chatelain, J. L., Guillier, B., \& Yepes, H. (1996). Tomography of the Ecuadorian Andes: Evidence for continuity of the Central Andes. C.R. Acad. Sci. Paris. Série 2. Sciences de la terre et des planètes, 323(10), 833-840.

Proust, J. N., Martillo, C., Michaud, F., Collot, J. Y., \& Dauteuil, O. (2016). Subduction of seafloor asperities revealed by a detailed stratigraphic analysis of the active margin shelf sediments of Central Ecuador. Marine Geology, 380, 345-362. https://doi.org/10.1016/ j.margeo.2016.03.014

Reyes, P. (2013). Evolution du relief le long des marges actives: Étude de la déformation Pli-Quaternaire de la Cordillère Côtière d'Equateur, Université de Nice Sophia Antipolis, PhD Thesis (in French).

Reyes, P., \& Michaud, F. (2012). Mapa Geológico de la Margen Costera Ecuatoriana (1:500.000), EPN, Petroecuador, IRD (Eds.), Quito-Ecuador.

Reyners, M., \& Eberhart-Phillips, D. (2009). Small earthquakes provide insight into plate coupling and fluid distribution in the Hikurangi subduction zone, New Zealand. Earth Planet. Science Letters, 282, 299-305.

Ruiz, M., Galve, A., Monfret, T., Sapin, M., Charvis, P., Laigle, M., et al. (2011). Seismic activity offshore Martinique and Dominica islands (Central Lesser Antilles subduction zone) from temporary onshore and offshore seismic networks. Tectonophysics, 68-78. https://doi.org/10.1016/ j.tecto.2011.08.006

Sage, F., Collot, J.-Y., \& Ranero, C. R. (2006). Interplate patchiness and subduction-erosion mechanisms; evidence from depth-migrated seismic images at the central Ecuador convergent margin. Geology, 34(12), 997-1000. https://doi.org/10.1130/G22790A.1

Sallarès, V., \& Charvis, P. (2003). Crustal thickness constraints on the geodynamic evolution of the Galapagos Volcanic Province. Earth Planet. Sci. Lett., 214(3-4), 545-559. https://doi.org/10.1016/S0012-821X(03)00373-X

Sallarès, V., Charvis, P., Flueh, E. R., Bialas, J., \& Party, S. S. (2005). Seismic structure of the Carnegie ridge and the nature of the Galapagos hotspot. Geophysical Journal International, 161(3), 763-788. https://doi.org/10.1111/j.1365-246X.2005.02592.x

Schwartz, S. Y., \& DeShon, H. R. (2007). Distinct updip limits to geodetic locking and microseismicity at the Northern Costa Rica Seismogenic Zone. In T. Dixon, \& J. C. Moore (Eds.), The Seismogenic Zone of Subduction Thrust Faults (pp. 576-599). New York: Columbia University. Press.

Schwartz, S. Y., \& Rokosky, J. M. (2007). Slow slip events and seismic tremor at Circum-Pacific subduction zones. Reviews of Geophysics, 45, RG3004. https://doi.org/10.1029/2006RG000208

Segovia, M. (2001). El sismo de Bahía del 4 de Agosto de 1998: Caracterización del mecanismo de ruptura y análisis de la sismicidad en la zona costera, Engineer Thesis, Escuela Politécnica Nacional, Quito, Ecuador, 126 p. (in Spanish).

Segovia, M. (2009). Análisis espacio-temporal del Enjambre de Puerto López entre enero y febrero de 2005 con observaciones de la estación de banda ancha de OTAVALO, Master Thesis, University of Nice Sophia Antipolis, Quito, Ecuador (in Spanish). 
Segovia, M., Font, Y., Régnier, M., Charvis, Ph., Nocquet, J.-M., Galve, A., et al. (2015). Intense microseismicity associated with a SSE at La Plata Island in the central subduction zone of Ecuador, 2015 AGU fall meeting, S31A-2736, Poster.

Simpson, R. W., Lienkaemper, J. J., \& Galehouse, J. S. (2001). Variations in creep rate along the Hayward Fault, California, interpreted as changes in depth of creep. Geophysical Research Letters, 28(11), 2269-2272. https://doi.org/10.1029/2001GL012979

Snoke, A. (2009). FOCMEC: FOCal MEChanims Determinations (focmec manual.pdf). http://ds.iris.edu/pub/programs/focmec

Takahashi, H., \& Kasahara, M. (2007). Spatial relationship between interseismic seismicity, coseismic asperities and aftershock activity in the Southwestern Kuril Islands, Geophysical Monograph Series. Washington DC: American Geophysical Union.

Tavera, H., Vilca, R., \& Marín, G. (2006). Inferences on the geometry of the Nazca Plate in Northwestern Perú based on data collected by a local seismograph network. Earth Sciences Research Journal, 10(1), 15-24.

Vaca, S., Régnier, M., Bethoux, N., Alvarez, V., \& Pontoise, B. (2009). Sismicidad de la región de Manta: Enjambre sísmico de Manta-2005. In J.-Y. Collot, V. Sallarès, \& A. Pazmiño (Eds.), Geología y Geofísica Marina y Terrestre del Ecuador desde la costa continental hasta las Islas Galápagos, PSE-001-2009 (in Spanish) (pp. 155-166). Guayaquil: Comisión Nacional del Derecho del Mar (CNDM).

Vaca, S., Vallée, M., Nocquet, J. M., Battaglia, J., \& Régnier, M. (2018). Recurrent slow slip events as a barrier to the northward rupture propagation of the 2016 Pedernales earthquake (Central Ecuador). Tectonophysics, 724-725, 80-92. https://doi.org/10.1016/ j.tecto.2017.12.012

Vallée, M., Nocquet, J.-M., Battaglia, J., Font, Y., Segovia, M., Régnier, M., et al. (2013). Intense interface seismicity triggered by a shallow SSE in the Central Ecuador subduction zone. Journal of Geophysical Research: Solid Earth, 118, 2965-2981. https://doi.org/10.1002/jgrb.50216

Villegas-Lanza, J. C., Chlieh, M., Cavalié, O., Tavera, H., Baby, P., Chire-Chira, J., \& Nocquet, J. M. (2016). Active tectonics of Peru: Heterogeneous interseismic coupling along the Nazca megathrust, rigid motion of the Peruvian Sliver and Subandean shortening accommodation. Journal of Geophysical Research: Solid Earth, 121, 7371-7394. https://doi.org/10.1002/2016/B013080

Witt, C., Bourgois, J., Michaud, F., Ordoñez, M., Jiménez, N., \& Sosson, M. (2006). Development of the Golfo de Guayaquil (Ecuador) as an effect of the North Andean block tectonic escape since the lower Pleistocene. Tectonics, 25, TC3017. https://doi.org/10.1029/2004TC001723 